OPEN ACCESS

Edited by:

James E. Goldman,

Columbia University, USA

Reviewed by: Janice R. Naegele,

Wesleyan University, USA

Francesca Ciccolini,

Heidelberg University, Germany

*Correspondence:

Nevena V. Radonjić

radonjic@uchc.edu

Specialty section:

This article was submitted to Neurogenesis,

a section of the journa

Frontiers in Neuroscience

Received: 06 June 2016 Accepted: 08 September 2016 Published: 30 September 2016

Citation:

Bagasrawala I, Zecevic N and Radonjić NV (2016) N-Methy

D-Aspartate Receptor Antagonist Kynurenic Acid Affects Human Cortical Development

Front. Neurosci. 10:435. doi: 10.3389/fnins.2016.00435

\section{N-Methyl D-Aspartate Receptor Antagonist Kynurenic Acid Affects Human Cortical Development}

\author{
Inseyah Bagasrawala ${ }^{1}$, Nada Zecevic ${ }^{1}$ and Nevena V. Radonjić ${ }^{2 *}$ \\ ${ }^{1}$ Department of Neuroscience, University of Connecticut Health, Farmington, CT, USA, ${ }^{2}$ Department of Psychiatry, University \\ of Connecticut Health, Farmington, CT, USA
}

Kynurenic acid (KYNA), a neuroactive metabolite of tryptophan degradation, acts as an endogenous $\mathrm{N}$-methyl-D-aspartate receptor (NMDAR) antagonist. Elevated levels of KYNA have been observed in pregnant women after viral infections and are considered to play a role in neurodevelopmental disorders. However, the consequences of KYNA-induced NMDAR blockade in human cortical development still remain elusive. To study the potential impact of KYNA on human neurodevelopment, we used an in vitro system of multipotent cortical progenitors, i.e., radial glia cells (RGCs), enriched from human cerebral cortex at mid-gestation (16-19 gestational weeks). KYNA treatment significantly decreased RGCs proliferation and survival by antagonizing NMDAR. This alteration resulted in a reduced number of cortical progenitors and neurons while number and activation of astrocytes increased. KYNA treatment reduced differentiation of RGCs into GABAergic neurons, while differentiation into glutamatergic neurons was relatively spared. Furthermore, in mixed cortical cultures KYNA triggered an inflammatory response as evidenced by increased levels of the pro-inflammatory cytokine IL-6. In conclusion, elevated levels of KYNA play a significant role in human RGC fate determination by antagonizing NMDARs and by activating an inflammatory response. The altered cell composition observed in cell culture following exposure to elevated KYNA levels suggests a mechanism for impairment of cortical circuitry formation in the fetal brain after viral infection, as seen in neurodevelopmental disorders such as schizophrenia.

\footnotetext{
Keywords: human fetal brain, cerebral cortex, tissue culture, KYNA, NMDARs, neurogenesis, cortical progenitor
} cells

\section{INTRODUCTION}

Kynurenic acid (KYNA) is an intermediate metabolite of the kynurenine pathway and the only naturally occurring antagonist of the glutamatergic NMDA receptor (NMDAR) in the human brain (Stone, 2013). In the brain, KYNA is synthesized in astrocytes by the irreversible transamination of L-kynurenine, the first major catabolic product of tryptophan. Elevated levels of KYNA have been found in the cerebrospinal fluid and in post-mortem brains of adult schizophrenia (Sch) patients (Erhardt et al., 2001; Schwarcz et al., 2001; Sathyasaikumar et al., 2011; Holtze et al., 2012). Both stress and infections, in rats activates indoleamine 2,3 dioxygenase (IDO), a cytokine responsive enzyme that catalyzes the formation of kynurenine, which may impair brain development (Pocivavsek et al., 2014; Notarangelo and Pocivavsek, 2016). Furthermore, environmental insults during development, such as maternal influenza infection, increase the risk 
for Sch and related disorders (Wright et al., 1995; Stöber et al., 2002; Limosin et al., 2003; Brown, 2012). In rodents, KYNA can cross the placental and fetal blood-brain barriers (Heyes et al., 1990; Scharfman and Goodman, 1998) and induce secretion of various pro-inflammatory cytokines, such as interferon gamma (IFN- $\gamma$ ) and interleukin 6 (IL-6), from fetal astrocytes (Meyer et al., 2011). Additionally, in vitro studies have demonstrated that IFN- $\gamma$ and IL- 6 can activate human fetal astrocytes to synthesize increased levels of KYNA (Guillemin et al., 2001). Thus, exposure of the fetal brain to KYNA may establish a positive feed-back loop, whereby KYNA levels are further enhanced (Guillemin et al., 2001; Meyer et al., 2011; Schwieler et al., 2015).

Glutamate acting via NMDARs has a trophic effect during development, and may play an important role in determining the selective survival of neurons and their proper connections (LoTurco et al., 1991; Haydar et al., 2000; Balasz, 2006). This is particularly pertinent to a possible role for disturbed NMDAR function in Sch, as an alteration or reduction of NMDARs has been demonstrated in medication-free Sch patients (Akbarian et al., 1996; Pilowsky et al., 2006), and abnormal glutamatergic activity has been reported in the pathophysiology of Sch (Deutsch et al., 1989; Coyle, 1996; Belforte et al., 2010). Furthermore, NMDARs are abundantly expressed in the developing human cerebral cortex at midgestation (Bagasrawala et al., 2016) Many animal models of Sch mimic a transient NMDAR hypofunction during development using NMDAR antagonists such as MK-801 (Ikonomidou et al., 1999), phencyclidine (PCP; Wang et al., 2001; Radonjić et al., 2008) and ketamine (Breier et al., 1997; Rujescu et al., 2006).

Even though it is known that there is a higher incidence of Sch in people exposed to viral infections in utero (Bale et al., 2010; Brown and Derkits, 2010; Selemon and Zecevic, 2015), presumably due to an inflammatory response and increased levels of KYNA, it is still unclear how elevated levels of KYNA affect the developing human brain. The goal of this study was to elucidate the role of KYNA as an endogenous NMDAR antagonist in the human fetal brain. As experimental manipulation of the developing human brain in vivo is not possible, we established an in vitro system to test the effects of KYNA on human cortical progenitor cells.

Radial glia cells (RGCs) are multipotent cortical progenitor cells capable of generating all neural cell types, including subpopulations of intermediate and interneuron progenitors, neurons, astrocytes and oligodendrocytes (Howard et al., 2006; Mo et al., 2007; Mo and Zecevic, 2009; Hansen et al., 2010, 2013; Lui et al., 2011; Yu and Zecevic, 2011; Ma et al., 2013; Radonjić et al., 2014). Specifically, we were interested in how exposure to KYNA affects survival, proliferation, and specification of RGCs into various cell types, including cortical interneurons and pyramidal cells. We demonstrated that elevated levels of KYNA, through a NMDAR blockade, not only reduced survival and proliferation of RGCs, but significantly altered the progeny of cortical RGCs. Treatment with KYNA promoted gliogenesis at the expense of neurogenesis, and increased activation of astrocytes. Moreover, we detected increased levels of a proinflammatory cytokine, IL-6, which suggests an initiation of an inflammatory response. The combined effects of a NMDAR blockade and an inflammatory response could impair cortical circuitry formation in utero and in so doing contribute to the pathophysiology of neurodevelopmental illness, possibly including the adult-onset disorder of schizophrenia.

\section{MATERIALS AND METHODS}

\section{Human Fetal Brain Tissue}

Human fetal brain tissue $(n=8)$, free of any developmental abnormalities, at 16-19 gw was obtained with written informed consent and the approval of University of Connecticut Health Ethics Committee, from the Human Developmental Biology Resource (Newcastle University, Newcastle upon Tyne, England) and the Tissue Repository of The Albert Einstein College of Medicine (Bronx, NY, USA), (Table 1). Transport of the human material was done on ice, following all necessary requirements and regulations set by the Institutional Ethics Committees, of our institution and respective tissue repositories.

The age of the tissue was determined by the following criteria: crown-rump length, weeks after ovulation, and anatomical landmarks. The tissue was transported on ice in Hank's Balanced Salt Solution (HBSS; Life Technologies, Grand Island, NY, USA) from the aforementioned brain repositories to the lab. A small unfixed piece $\left(1 \mathrm{~cm}^{2}\right)$ of the dorsal telencephalic region was used to generate dissociated cell cultures (Zecevic et al., 2005; Radonjić et al., 2014). We always tried to used multiple methods on the same case, but not all the cases were available for every method used in this study, as specified in Table 1.

\section{Dissociated Mixed Cell Culture and Enrichment of RGCs}

A previously published protocol (Mo and Zecevic, 2009) was used to establish dissociated mixed cell cultures. As briefly described here, the isolated tissue was dissociated mechanically and enzymatically at $37^{\circ} \mathrm{C}$ for $30 \mathrm{~min}$ with $0.025 \%$ trypsin (Gibco, Beverly, MA, USA), followed by addition of DNase (SigmaAldrich, St Louis, MO, USA; $2 \mathrm{mg} / \mathrm{mL}$ ), washing with HBSS (Life Technologies) and suspension in proliferation medium (PM; Figure 1A). The PM consisted of DMEM/F12 (Life Technologies) supplemented with $10 \mathrm{ng} / \mathrm{mL}$ of basic fibroblast growth factor (bFGF, Peprotech, Rocky Hill, NJ, USA), 10 ng/mL of epidermal growth factor (EGF, Millipore, Billerica, MA, USA),

TABLE 1 | Description of human fetal tissue and methods used.

\begin{tabular}{llcl}
\hline $\begin{array}{l}\text { Case } \\
\text { number }\end{array}$ & Sex & $\begin{array}{c}\text { Gestational } \\
\text { week }\end{array}$ \\
\hline 1 & MALE & 16 & qPCR, Western blot, Immunocytochemistry, ELISA \\
2 & MALE & 17 & qPCR, Western blot, Immunocytochemistry, ELISA \\
3 & MALE & 18 & qPCR, Western blot, Immunocytochemistry, ELISA \\
4 & MALE & 19 & qPCR, Western blot, Immunocytochemistry, ELISA \\
5 & MALE & 16 & Immunocytochemistry (Mixed cells), ELISA \\
6 & MALE & 18 & Immunocytochemistry (Mixed cells), ELISA \\
7 & MALE & 18 & Immunocytochemistry (Mixed cells), ELISA \\
8 & MALE & 19 & Immunocytochemistry (Mixed cells), ELISA
\end{tabular}


A

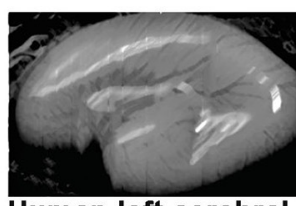

Human left cerebral hemisphere at $17 \mathrm{gw}$

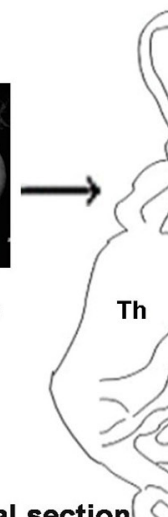

Coronal section through the hemisphere

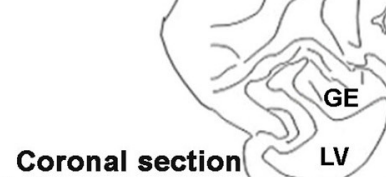

B

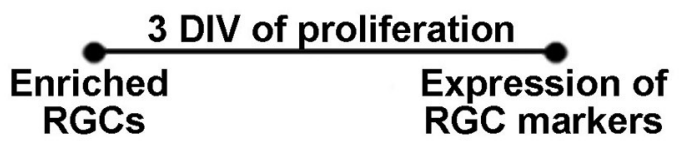

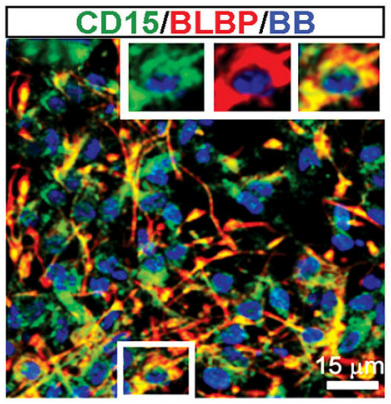

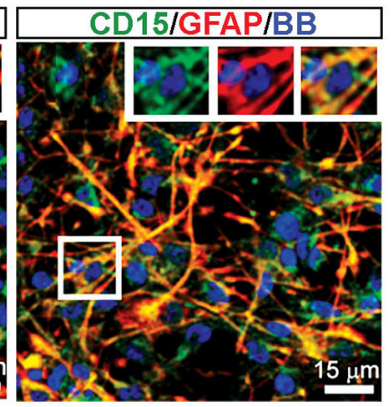

FIGURE 1 | Enriched RGCs from human fetal cortex using MACS. (A) Dissociated mixed cell cultures are established from the telencephalic wall (red box), and RGCs are enriched from these cultures through magnetic sorting (MACS) using anti-CD15 micro-beads. (B) Enriched RGCs are co-labeled for CD15 and radial glia markers BLBP or GFAP after 3 DIV of proliferation. Nuclear stain: bisbensimide (BB).

and B27 (Life Technologies). Seven to ten days after plating, the cells proliferated in PM and reached $80 \%$ confluency whereupon they were used for experiments on activated astrocytes including sandwich ELISA, and to generate RGC cultures.

RGCs were isolated from mixed cell cultures using the cell surface glycan marker CD15 via magnetic columns (MACS, Miltenyi Biotec, Auburn, CA, USA) (Mo et al., 2007; Radonjić et al., 2014). Enriched RGCs were fixed after 2 hrs and co-labeled for surface antigen CD15 and either brain lipid binding protein (BLBP; 97.8\%) or glial fibrillary acidic protein (GFAP; 99.1\%), both markers of RGCs (Figure 1B), demonstrating the purity of enriched RGC cultures. The expression of the NR1 gene and protein in cell lysates as well as NR1 expression on different cell types using double immunostaining, was done after 3 days in vitro (DIV) in PM, and after 7 DIV in differentiation medium (DM), which is devoid of growth factors. RGCs plated on polyD-lysine (Sigma-Aldrich) coated coverslips $(12 \mathrm{~mm})$ at a density of 250,000 cells/ml were used for immunocytochemistry. PolyD-lysine coated six wells $\left(10 \mathrm{~cm}^{2}\right.$ growth area/well $)$ plated with 2 million cells/ml were used to collect cell lysates for total protein and RNA isolation.

\section{Pharmacological Treatments of Cell Cultures}

RGCs cultures were treated with each of these substances: KYNA, NMDAR-specific antagonist D-amino phosphonovalerate
(D-APV), and nicotinic acetylcholine receptor (nAChR) antagonist Tubocurarine chloride (TBC), to determine if the effect of KYNA was mediated through NMDARs or nAChRs. Concentration-response curves were first plotted $48 \mathrm{~h}$ after RGC cultures underwent treatments with eight different concentrations (0.001-100.0 $\mu \mathrm{M}$ ) of KYNA (Sigma Aldrich), D-APV (Tocris Biosciences, Bristol, UK) and TBC. KYNA was dissolved in DMSO (Dimethyl sulphoxide, Sigma Aldrich), and therefore two sets of controls were maintained: (1) RGCs grown only in PM, (2) RGCs grown in PM containing DMSO. In all analyzed experiments there was no difference between control $\mathrm{PM}$ and $\mathrm{PM}+\mathrm{DMSO}$, hence $\mathrm{PM}+\mathrm{DMSO}$ results were represented in graphs as the control. The effective concentration at which $50 \%$ of the cell population was affected (EC50) was determined in both assays to decide the treatment concentrations to be used for further experiments, where cells were analyzed after 3 DIV in PM, and after 7 DIV in DM.

\section{Cell Survival Assay}

A live/dead assay (Molecular Probes, Eugene, OR, USA) was performed after $48 \mathrm{~h}$ of KYNA treatment to assess its effect on cell viability. The kit enables detection of live cells via the cell-permeant molecule calcein acetoxymethyl that gives a green fluorescence in the presence of intracellular esterases. Dead cells which have lost the intact cell membrane appear red due to incorporation of an ethidium homodimer into their degrading nucleic acids. 


\section{Proliferation Assay}

At the end of the $48 \mathrm{~h}$ KYNA treatment period, cells were fixed and immunostained with anti-Ki67 antibody. Ki67 is a marker of cells undergoing mitotic divisions or proliferation. The percentage of $\mathrm{Ki}^{+} 7^{+}$cells was determined from the total number of cells marked with the nuclear stain bisbenzimide (BB).

\section{Immunocytochemistry (ICC)}

Cells growing in vitro on coverslips were fixed with $4 \%$ paraformaldehyde, washed with PBS (phosphate buffer saline), blocked $(0.2 \%$ bovine serum albumin (BSA), $0.01 \%$ Triton X$100, \mathrm{PBS}$ ) for $1 \mathrm{~h}$ at room temperature (RT), and incubated with primary antibodies (see Table 2 ) at $4^{\circ} \mathrm{C}$ overnight. The specificity of each primary antibody has been previously tested and shown in the data sheets obtained from the respective manufacturers. Specificity of staining was validated by replacing the primary antibody with the normal serum from the animal in which the antibody was produced, which resulted in the absence of fluorescent signal. The following day, fluorophore-conjugated secondary antibodies goat anti-mouse Alexa-488 (Jackson ImmunoResearch, Lot no. 104763), and goat anti-rabbit Alexa555 (Molecular Probes, Catalog no. A21428) at a concentration of $1 \mu \mathrm{g} / \mathrm{ml}$ each were applied for $2 \mathrm{~h}$ at RT, followed by the nuclear stain BB for $1 \mathrm{~min}$. All immunostained coverslips were mounted using the anti-fade reagent Fluoromount-G (Southern Biotech, Birmingham, AL, USA) to preserve the fluorescence.

\section{Image Analysis and Statistical Tests}

Immunolabeled samples were visualized using an Axioscope microscope (Zeiss, Germany) equipped with Axiovision software and photographed using a digital camera with 63X lens. During acquisition of images of double immunolabeled sections the focus, brightness and contrast were constant. Twelve random images were taken from each coverslip and analyzed in Adobe Photoshop (v. 7.0), with consistent quality adjustments for contrast, brightness and color balance and used for cell counting.

We quantified cells labeled with each marker in its respective channel in Photoshop, as well as cells that show immunoreaction for both applied antibodies. The total cell number in the optical field was determined by quantifying cell nuclei labeled with a nuclear dye bisbensamide (BB). The percentage of double labeled cells was then calculated from a total cell count and averaged across the four coverslips/12 pictures/4 brains for each marker and each treatment and plotted in the bar graphs.

\section{Western Blot (WB)}

Cells were homogenized in lysis buffer $(50 \mathrm{mM}$ Tris- $\mathrm{HCl} \mathrm{pH}$ 7.4, $150 \mathrm{mM} \mathrm{NaCl}, 1 \% \mathrm{NP}-40,1 \mathrm{mM}$ phenylmethylsulfonyl fluoride, Sigma Aldrich, and protease inhibitor cocktail, Thermo Scientific, Agawam, MA, USA) on ice for $30 \mathrm{~min}$, centrifuged at $14,000 \times \mathrm{g}$ for $15 \mathrm{~min}$ at $4^{\circ} \mathrm{C}$, and the supernatants were collected as the cell lysates. The protein content of the samples was analyzed using the BCA protein estimation colorimetric assay (Thermo Scientific). Twenty micrograms of protein was loaded in each well and proteins were separated on 4-15\% gradient polyacrylamide gels (Bio-Rad, Portland. ME, USA) at $110 \mathrm{v}$ for $75 \mathrm{~min}$. Samples were run, on three separate gels, to obtain results in triplicates. The separated proteins were transferred onto polyvinylidene fluoride (PVDF) membranes at $100 \mathrm{v}$ for $60 \mathrm{~min}$. A Ponceau stain on every blot, and a Coomassie stain for every gel was performed to confirm complete transfer of separated proteins. After blocking with 5\% milk in TBS-T (1.0\% Tween-20, PBS, 0.1\% Triton X-100, distilled water; $\mathrm{pH} 7.4$ ), the membrane (blot) was incubated with primary antibodies diluted in blocking solution $(0.1 \mathrm{M}$ Tris, $2 \%$ nonfat dry milk, $0.15 \mathrm{M} \mathrm{NaCl}, 0.01 \% \mathrm{Na}$-azide, $\mathrm{pH}$ 7.4) against the proteins of interest at $4{ }^{\circ} \mathrm{C}$ (Table 2) overnight. The blot was washed three times, with $1 \mathrm{X}$ TBS-T (10\% Tween, PBS, $0.1 \%$ TritonX-100, distilled water), and incubated with horseradish peroxidase (HRP)-conjugated secondary antibodies (Millipore) for $2 \mathrm{~h}$ at RT., Blots were incubated with SuperSignal West Dura Extended Duration Substrate (Thermo Scientific), and imaged on ChemiDoc MP (Bio-Rad) digital imaging system. The loading control for each blot was GAPDH (primary antibody dilution 1:5000). Each membrane was used only once, no stripping or re-probing has been performed. The density of each band was determined in Adobe Photoshop (v.7.0) using histogram analysis. The values obtained for each band were divided by the value of the corresponding GAPDH band. The averaged values obtained from KYNA treated groups were normalized to

TABLE 2 | List of primary antibodies used.

\begin{tabular}{|c|c|c|c|c|c|}
\hline Primary antibody & Cell type identified & Species & Concentration & Catalog number & Company \\
\hline CD15 & Radial Glia (RGC) & Mouse & $2 \mu \mathrm{g} / \mathrm{ml}$ & \#MS-1259-P & Thermo Scientific \\
\hline BLBP & RGC & Rabbit & $1.25 \mu \mathrm{g} / \mathrm{ml}$ & ab27171 & Abcam \\
\hline GFAP & RGC, Astrocyte & Mouse, rabbit & $5 \mu \mathrm{g} / \mathrm{ml}$ & Z 0334 & Dako \\
\hline Tbr2 & Intermediate Progenitor & Rabbit & $2 \mu \mathrm{g} / \mathrm{ml}$ & ab23345 & Abcam \\
\hline Nkx2.1 & Interneuron Progenitor & Rabbit & $10 \mu \mathrm{g} / \mathrm{ml}$ & $a b 76013$ & Abcam \\
\hline$\beta$ III tubulin & Neuron & Mouse, rabbit & $2 \mu \mathrm{g} / \mathrm{ml}$ & 065M4820V & Sigma-Aldrich \\
\hline Tbr1 & Glutamatergic Neuron & Rabbit & $5 \mu \mathrm{g} / \mathrm{ml}$ & 20932-1-AP & Proteintech \\
\hline GABA & Interneuron & Rabbit & $5 \mu \mathrm{g} / \mathrm{ml}$ & A2052 & Sigma-Aldrich \\
\hline CalR & Interneuron & Rabbit & $1 \mu \mathrm{g} / \mathrm{ml}$ & $7699 / 4$ & Swant \\
\hline Ki67 & Proliferating Cells & Rabbit & $1 \mu \mathrm{g} / \mathrm{ml}$ & ab15580 & Abcam \\
\hline GAPDH & Housekeeping & Mouse & $0.2 \mu \mathrm{g} / \mathrm{ml}$ & MAB374 & Millipore \\
\hline NR1 & - & Mouse & $10 \mu \mathrm{g} / \mathrm{ml}$ & $75-272$ & NeuroMab \\
\hline
\end{tabular}


TABLE 3 | List of primers used for qPCR.

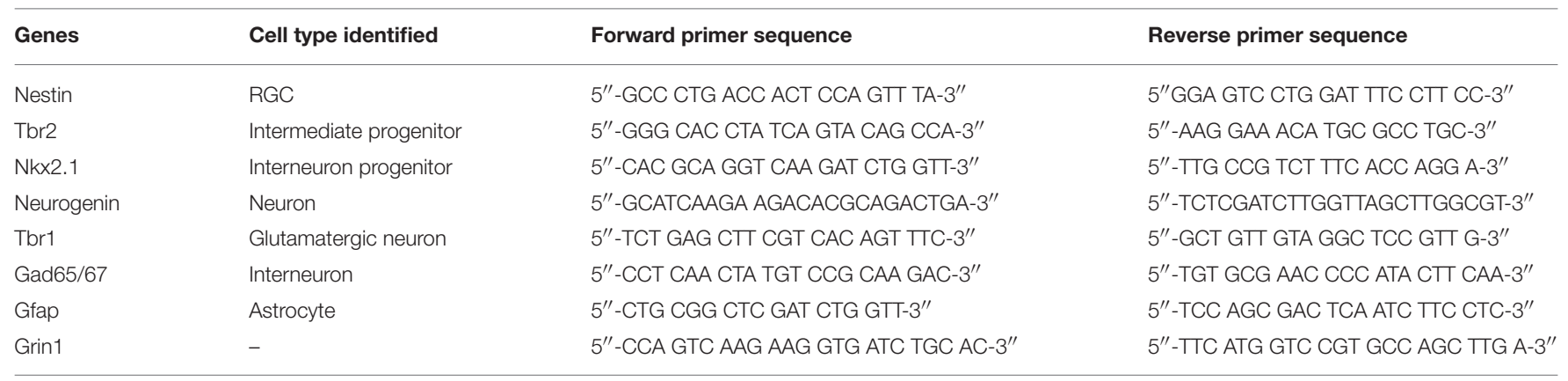

the control (DMSO) group to overcome individual differences between samples.

\section{Real-Time Polymerase Chain Reaction}

Cells were treated with ice-cold TRIZOL ${ }^{\circledR}$ reagent (Invitrogen, Carlsbad, CA, USA; $1 \mathrm{ml} / 10 \mathrm{~cm}^{2}$ of surface area) and were broken down mechanically and through alternate freeze-thaw cycles. Chloroform $(200 \mu \mathrm{l} / 1 \mathrm{ml}$ of Trizol) was added to the homogenates, and tubes were vortexed, incubated (15 $\mathrm{min}$ at $\left.4^{\circ} \mathrm{C}\right)$, and centrifuged $\left(13,000 \times \mathrm{g}\right.$ for $15 \mathrm{~min}$ at $\left.4^{\circ} \mathrm{C}\right)$. The upper transparent phase was collected in sterile tubes, incubated with isopropanol (500 $\mu \mathrm{l} /$ tube; $20 \mathrm{~min}$ at RT), and centrifuged $\left(13,000 \times \mathrm{g}\right.$ for $15 \mathrm{~min}$ at $\left.4^{\circ} \mathrm{C}\right)$. The pellets were incubated with $75 \%$ ethanol $\left(4^{\circ} \mathrm{C}\right)$ and centrifuged $(13,000 \times$ $\mathrm{g}$ for $15 \mathrm{~min})$. The pellets containing RNA were air dried and dissolved in 5\% RNase Out solution. RNA concentrations were determined using the NanoDrop technology. cDNA was synthesized by reverse transcriptase-PCR using the First Strand Synthesis SuperScript III kit (Invitrogen). The SYBR Green (Applied Biosystems, Cheshire, UK) protocol was used to analyze the expression levels of mRNA from the cDNA samples (see Table 3 for list of genes and primers) by performing real time PCR using the CFX96 Connect ${ }^{\circledR}$ thermocycler (Bio$\mathrm{Rad})$. The real time PCR protocol involves a heating step to $95^{\circ} \mathrm{C}$ for $2 \mathrm{~min}$ followed by 40 cycles at $95^{\circ} \mathrm{C}$ for $15 \mathrm{~s}$, at $55^{\circ} \mathrm{C}$ for $15 \mathrm{~s}$, and at $68^{\circ} \mathrm{C}$ for $20 \mathrm{~s}$. Cycle of threshold $\left(C_{t}\right)$ values were used to calculate the $\Delta \Delta C_{t}$ values, and the formula $2^{-\Delta \Delta C t}$ was used to determine the mRNA expression level relative to the control sample which has an arbitrary value of 1 .

\section{Sandwich Enzyme Linked Immunosorbent Assay (Sandwich ELISA)}

The eBioscience High Sensitivity human anti-IL6 ELISA (San Diego, CA) kit was used for the sandwich ELISA experiments on dissociated mixed cell cultures prepared from four fetal brains (16-19 gw). The assay was performed according to manufacturer's instructions. We used Origin to plot the standard curve and analyze results from the ELISA experiment.

\section{Statistics}

All data were expressed as mean \pm standard error of mean (SEM). Mean, SEM, and $p$-values were calculated in Microsoft Excel. For all experiments, data were averaged across the four brains $(n=$ 4 ; $16-19 \mathrm{gw})$. Two-tailed Student's $t$-test was used to compare treated and control groups with statistical significance considered $p \leq 0.05$.

\section{RESULTS}

\section{Cortical Progenitors and Neurons Express NR1 at Mid-Gestation}

Using the enriched dorsal RGCs cultures (see Materials and Methods; Figure 1), we explored whether isolated RGCs express NMDARs, particularly the obligatory subunit NR1, since KYNA has a specific affinity toward the glycine site of the NR1 subunit (Zhuravlev et al., 2007). Indeed, cultured human RGCs express the NR1 subunit gene (Figures 2A,B) and protein (Figure 2C) after 3 DIV of proliferation and 7 DIV of differentiation in all fetal brains studied ( $n=4,16-19 \mathrm{gw}$ ). Further, to determine which progenitor subtypes express the NR1 subunit after 3 DIV we used double immunolabeling with antibodies against NR1 and the markers of cortical progenitors (Figure 2D). We demonstrated that RGCs labeled with $\mathrm{BLBP}^{+}$, intermediate progenitors labeled with $\mathrm{Tbr} 2^{+}$, and a subpopulation of interneuron progenitors labeled with $\mathrm{Nkx} 2.1^{+}$, all express the NR1 subunit. After 7 DIV of differentiation, the newly generated neurons labeled with $\beta I I I$ tubulin, and also with Tbrl or GABA, markers of glutamatergic and cortical interneurons, respectively, express NR1 (Figure 2D). In humans, GFAP is a marker of both RGCs progenitors and differentiated astrocytes, and both cell types express NR1 subunit. Notably, we observed two types of immunostaining: diffused staining in progenitor cells, possibly due the presence of NR1 in the Golgi network undergoing transport, and punctate staining in neurons, which could reflect membrane localization of NR1 in these cells.

Thus, based on these co-labeling experiments, we conclude that at mid-gestation, both cortical progenitors, two neuronal subtypes, glutamatergic and interneurons, and astroglia cells express the NR1 subunit of NMDARs.

\section{KYNA Affects Cell Survival and Proliferation via Blockade of NMDARs}

We further examined the effects of KYNA on proliferation and survival of human RGCs. KYNA binds to the NR1 subunit of NMDARs as well as to the nAChRs. To determine if the effect 
A

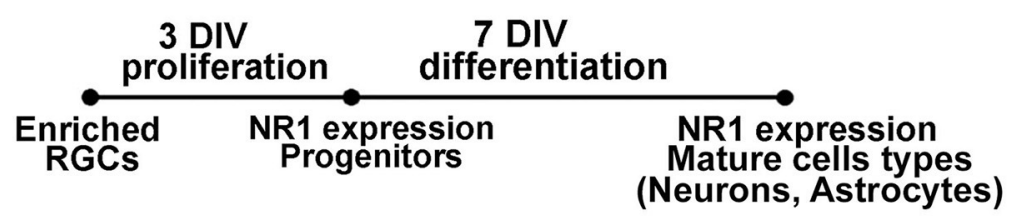

B

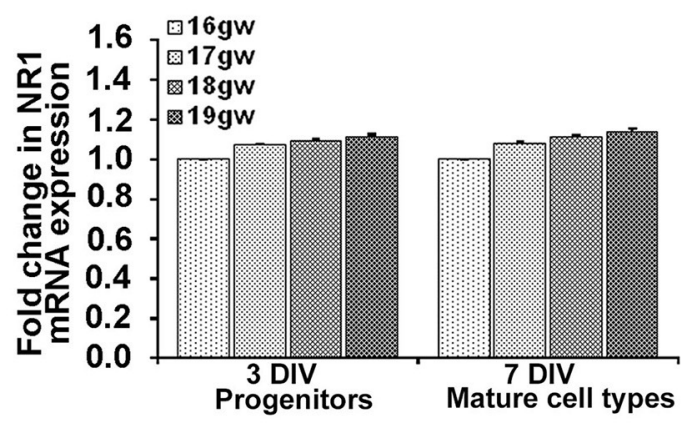

C

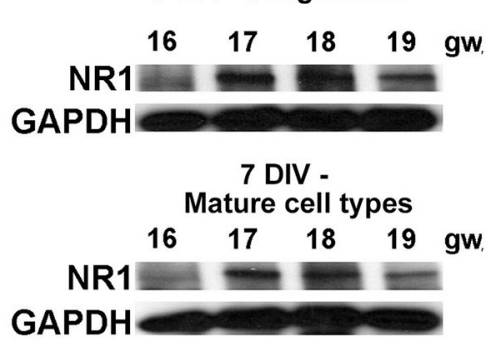

D
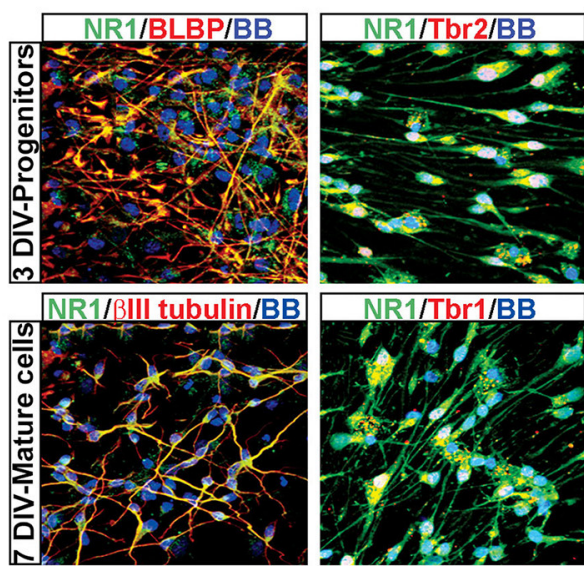
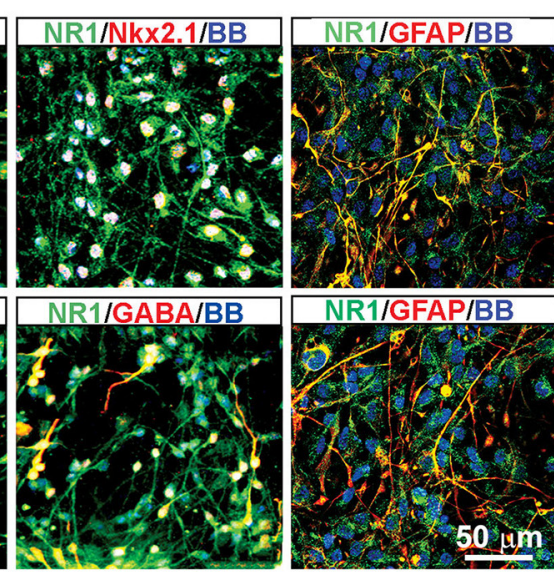

FIGURE 2 | Cell types that express NR1 subunit at mid-gestation. (A) Timeline showing that NR1 expression was analyzed on progenitors after 3 DIV in PM and on mature cell types after 7 DIV in DM; $n=4$. (B) qPCR and (C) Western blot showing NR1 gene and protein expression, respectively, mean \pm SEM. (D) Representative double immunolabeling images taken from $17 \mathrm{gw}$ cultures for NR1 (green) with either progenitor, neuronal or astroglial markers (red). After 3 DIV in PM, NR1 was expressed on BLBP+ RGCs, Tbr2+ intermediate progenitors, Nkx2.1 $1^{+}$interneuron progenitors, and on GFAP ${ }^{+}$astroglia. After additional 7 DIV in DM, NR1 was expressed on neurons labeled with $\beta$ III tubulin, Tbr1, GABA, and on astrocytes labeled with GFAP. Nuclear stain: BB.

of KYNA on cell cycle and cell death was mediated through NMDARs or nAChRs, we used receptor specific antagonists: D-APV specific to NMDARs and TBC for nAChRs (Figure 3A).

Response curves were first plotted $48 \mathrm{~h}$ after RGC cultures underwent treatments with eight different concentrations of KYNA, D-APV, and TBC. The effect of KYNA on RGCs proliferation and on cell survival was measured, and the effective concentration at which $50 \%$ of the cell population was affected (EC50) was determined in both assays. Considering that the concentration $0.05 \mu \mathrm{M}$ effectively induced $50 \%$ cell death and concentration $0.01 \mu \mathrm{M}$ effectively inhibited $50 \%$ of cell proliferation (Figures 3B,C), we used the following treatment concentrations for further experiments: 0.001, 0.005, and 0.01 $\mu \mathrm{M}$ of KYNA for $48 \mathrm{~h}$. Furthermore, KYNA concentrationresponse curves in both assays were similar to that of D-APV while TBC curves were shifted to the right, suggesting that in human RGC cultures KYNA exerts most of its effects on cell survival and proliferation in a manner very similar to the NMDAR-specific antagonist D-APV.

\section{KYNA Alters RGC Specification}

To examine the effects of KYNA on the specification of human cortical progenitors, we followed the progeny of RGCs after 3 DIV of proliferation. Real-time PCR revealed that after KYNA treatment expression of genes specific to progenitor subtypes is decreased in a concentration-dependent manner, while expression of the astroglial gene, Gfap is increased with the highest KYNA concentration of $0.01 \mu \mathrm{M}(p<0.05$; Figure 4A).

Protein expression, examined in whole cell lysates using Western blotting, revealed that treatment with KYNA significantly reduced expression levels of proteins specific for cortical progenitors. While only the highest concentration of KYNA $(0.01 \mu \mathrm{M})$ had significant $(p<0.05)$ effects on RGC 
A

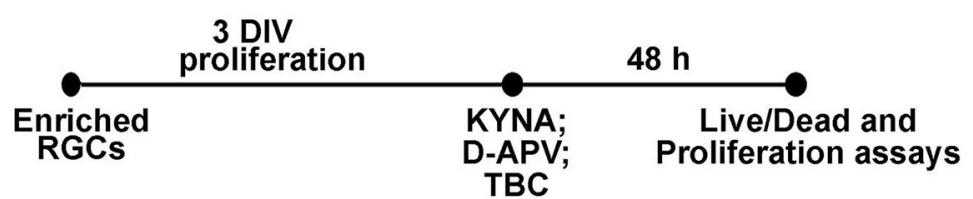

B

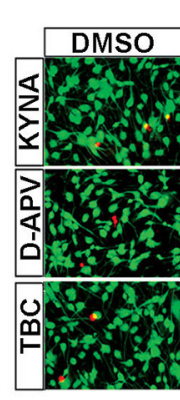

C

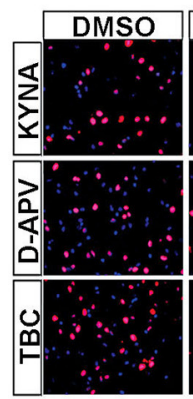

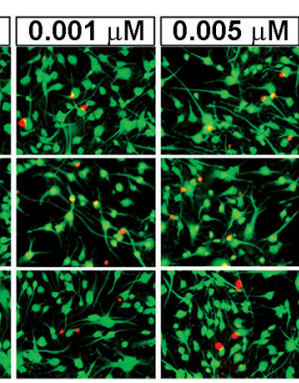
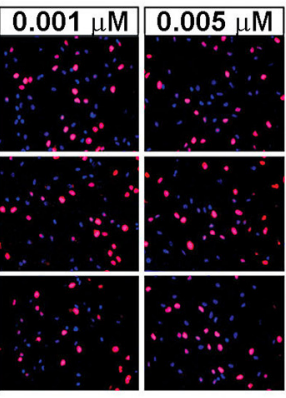
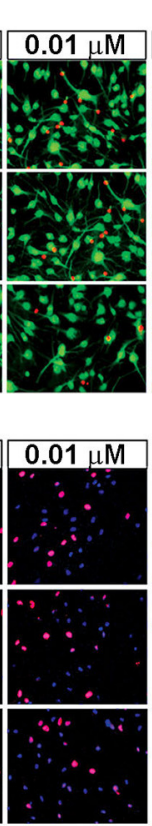
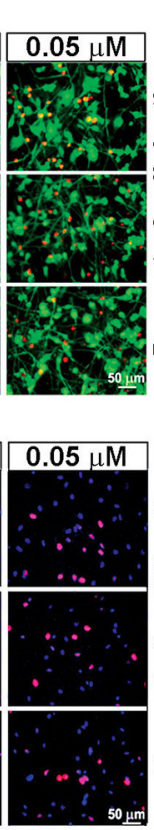

Concentration-response curve

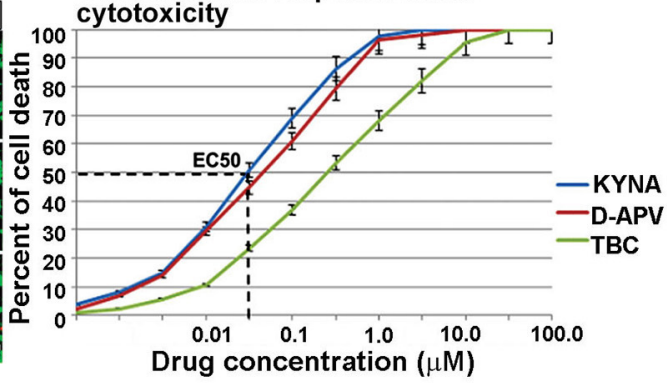

Concentration-response curve

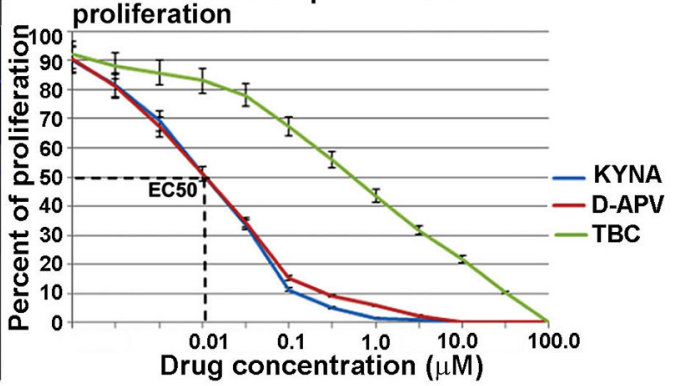

FIGURE 3 | Concentration-response curve for in vitro KYNA treatment. (A) Timeline of the experiment. (B) The live/dead assay: live (green) and dead cells (red) for control (DMSO) and drug treatments. (C) Ki67 $7^{+}$proliferating cells (red); nuclear stain BB (blue); $n=4 ; p<0.05$ between DMSO and each treatment. Mean \pm SEM; DMSO, Dimethyl sulfoxide; TBC, Tubocurarine chloride; D-APV, D-amino phosphonovalerate.

protein BLBP and intermediate progenitor protein Tbr2, all three concentrations of KYNA reduced expression of protein Nkx2.1 present in subpopulation of cortical interneuron progenitors $(p$ $<0.05$ ). In accordance with gene expression levels, astroglial protein GFAP showed an increase after KYNA treatment in a concentration-dependent manner $(p<0.05$; Figures 4B,C).

Looking at the effects of KYNA on the cell types using immunocytochemistry, we found that the percentage of $\mathrm{BLBP}^{+}$ RGCs and $\mathrm{Tbr}^{+}$intermediate progenitors from all cells in the culture were significantly reduced with the two highest concentrations $(0.005$ and $0.01 \mu \mathrm{M})$, while all three concentrations of KYNA significantly decreased the percentage of Nkx2.1 $1^{+}$interneuron progenitors $(p<0.05)$. These results were in line with those observed from the qPCR and Western blotting experiments. Similar to data on gene and protein expression, we found a significant increase in the GFAP ${ }^{+}$ astroglial population in KYNA treated cultures $(p<0.05$; Figures 4D,E).

These results indicate that KYNA significantly altered the specification of the cortical radial glia progenitor cells by reducing the number of progenitor subtypes (Tbr2, Nkx2.1) while increasing the number of $\mathrm{GFAP}^{+}$astroglial cells, the first type of glia to appear once neurogenesis is completed in vivo. This alteration in the progenitor specification timeline is likely to alter the downstream process of neurogenesis and gliogenesis.

\section{KYNA Modifies the Process of Neuronal Differentiation}

Since KYNA negatively affected RGCs and altered their specification process, we hypothesized that the process of progenitor cells differentiating into cortical neurons is also affected. In order to test our hypothesis, we added differentiation medium (DM) to our progenitor cell cultures for 7 DIV and then assessed their differentiation into either neurons or astrocytes.

Gene expression analysis using real time PCR showed that KYNA decreased expression of neuronal genes Neurogenin $1 / 2$, Tbr1, and Gad65 in a concentration-dependent manner, but increased expression of astrocytic gene Gfap $(p<0.05$; Figure 5A). This finding was further supported by the decrease in neuronal proteins $\beta$ III tubulin and Tbr1, but an increase in astrocytic protein GFAP after KYNA treatment $(p<0.05$; Figures 5B,C). Although we demonstrated decrease in mRNA levels in progenitors (Figure 4A) as well as in neurons and astrocytes (Figure 5A), we need to take into account that a pharmacological treatment affects the viability of the cells which limits the interpretation of these results. 


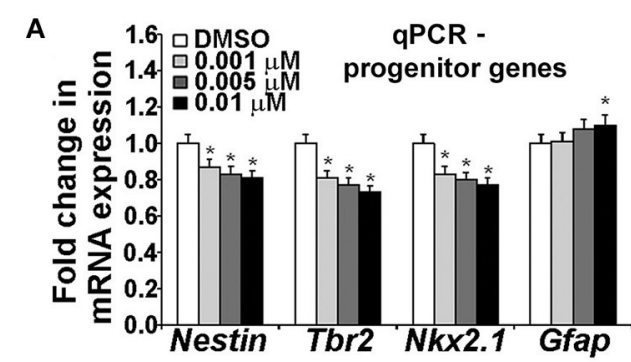

B Western blot - progenitor proteins

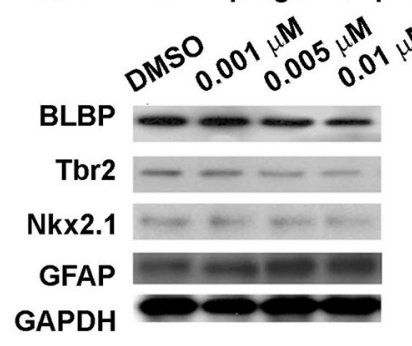

C

Densitometric analysis
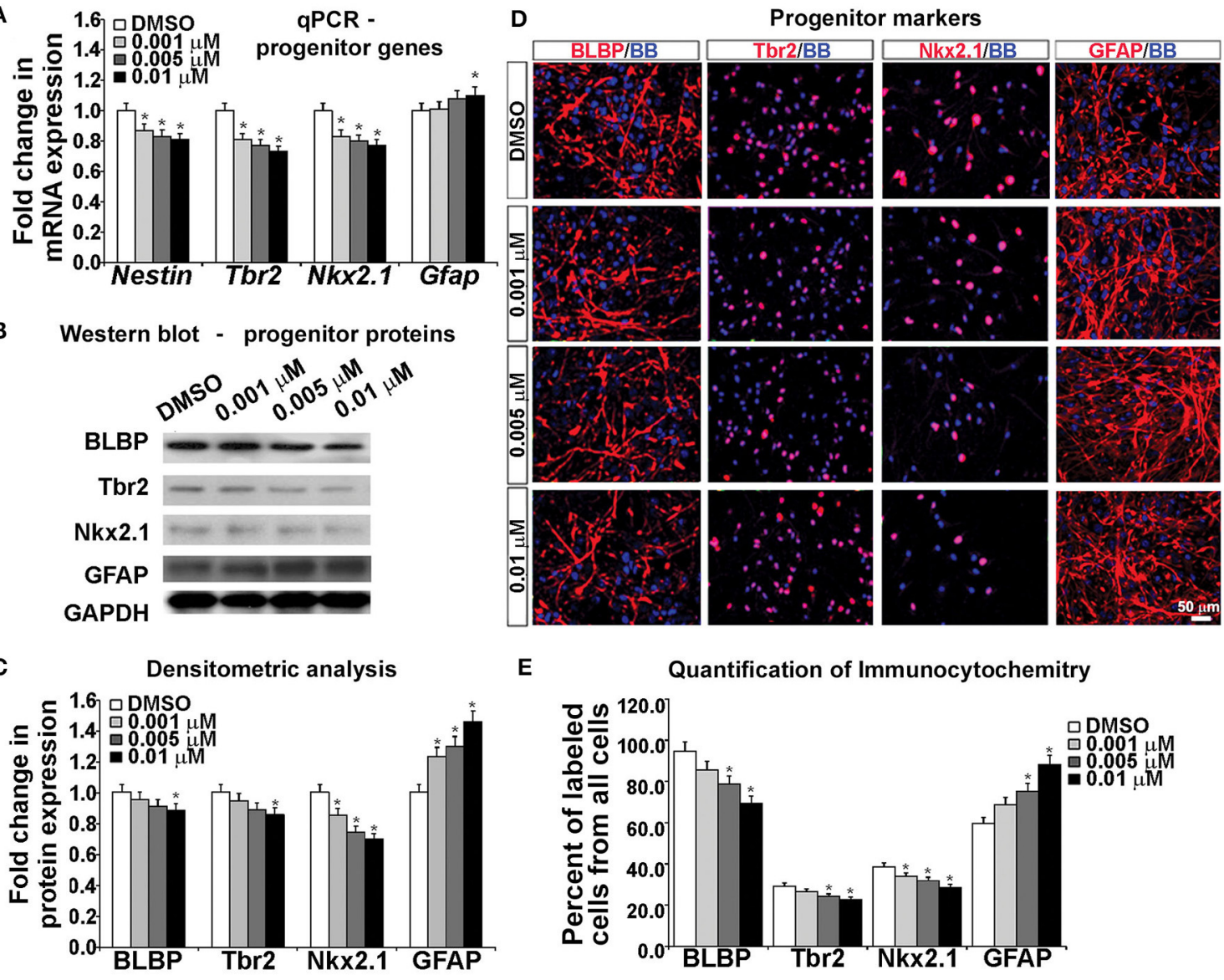

E

Quantification of Immunocytochemitry

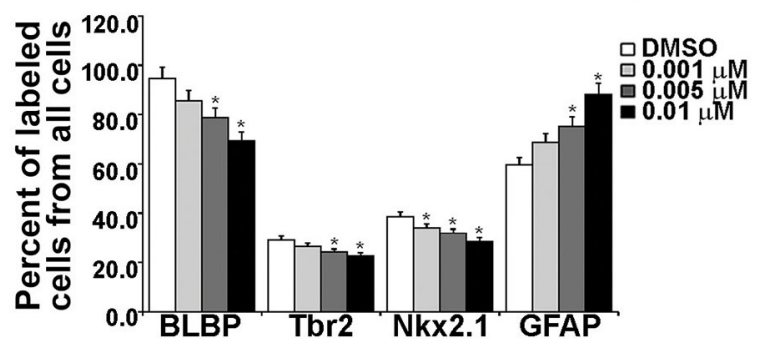

FIGURE 4 | Blocking NMDAR affects cell fate determination in vitro. (A) KYNA treatment decreased progenitors but increased astroglia specific gene expression in a concentration-dependent manner, (B) Western blot from $17 \mathrm{gw}$ KYNA treated cell lysates, and (C) the densitometric analysis showed a decrease in progenitor, but increase in astroglia protein expression in a concentration-dependent manner. (D) Representative images at 17 gw for immunolabeling with specific progenitor and astroglia markers (red), and nuclear stain: BB (blue). (E) The immunolabeling quantification showed a decrease in percentage of progenitor subtypes, but an increase in astroglia population ( $n=4$; ${ }^{*}$ represents $\left.p<0.05\right)$. Scale bar $50 \mu \mathrm{m}$.

To analyze the effect on specific cell-types, we performed immunocytochemistry using antibodies specific to neuronal proteins. We observed a significant decrease in the number of cells labeled with neuronal markers ( $\beta$-III-tubulin, Tbr1, GABA, Calretinin) and this decrease was KYNA concentrationdependent. Moreover, the decrease of GABAergic neurons was $50 \%$ and glutamatergic (Tbr1) neurons 17\% comparing to controls, suggesting a greater effect of KYNA on interneuron vs. glutamatergic neurogenesis. Once again, we found an increase in the number of $\mathrm{GFAP}^{+}$astrocytes, indicating a drive toward astrocyte formation $(p<0.05$; Figures 5D,E). We have not, however, observed any differences in oligodendrocyte progenitors $\left(\mathrm{O}^{+}\right.$cells) or mature oligodendrocytes $\left(\mathrm{MBP}^{+}\right.$ cells) in our KYNA treated cultures (not shown).

Combined results obtained with a battery of methods demonstrated that KYNA influenced the RGC specification and differentiation process by increasing the astroglial cell population at the expense of neuronal cells. Developmentally, this shift in gliogenesis occurring before neurogenesis could be detrimental to cortical circuitry formation and function.

\section{KYNA Treatment Increases the Population of Reactive Astrocytes}

It has been previously reported that KYNA triggers activation of astrocytes and generates an inflammatory response that involves secretion of pro-inflammatory cytokines (Guillemin et al., 2001; Meyer et al., 2011). To test this possibility, we used mixed cell cultures that contain both neurons and glia cells, and have a higher number of astroglial cells $\left(\mathrm{GFAP}^{+}\right)$than the enriched RGC cultures (Figure 6A; Mo et al., 2007). We treated mixed cortical cultures with the same concentrations of KYNA as used for the enriched RGC cultures, i.e., 0.001, 0.005, and $0.01 \mu \mathrm{M}$, for 24 and $48 \mathrm{~h}$ and performed cell survival and proliferation assays as previously described. The highest level of KYNA used, $0.01 \mu \mathrm{M}$, induced $30 \%$ more cell death compared to control (Figure 6B; $p<0.05$ ), and decreased cell proliferation by $21.4 \%$ compared to control (Figure 6C; $p<0.01$ ). We immunolabeled 

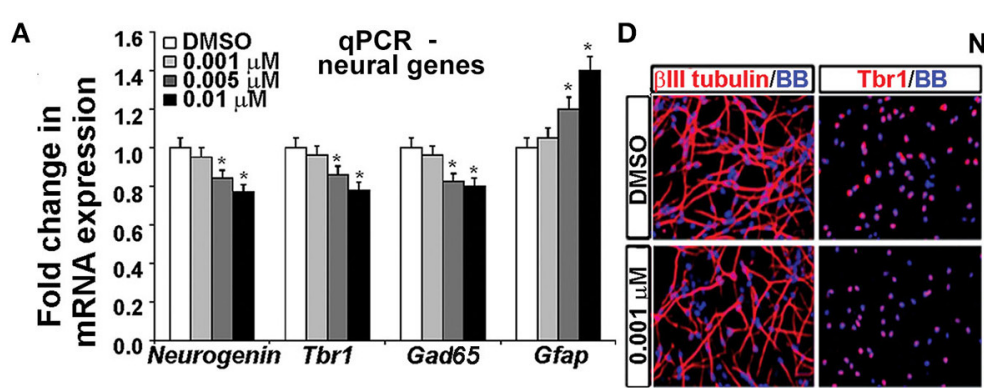

Neural markers

B

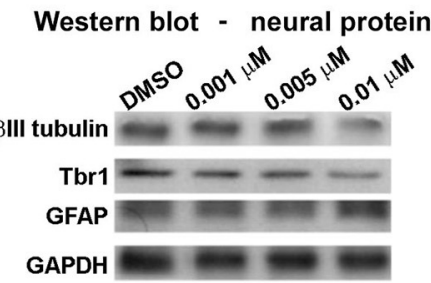

C

Densitometric analysis
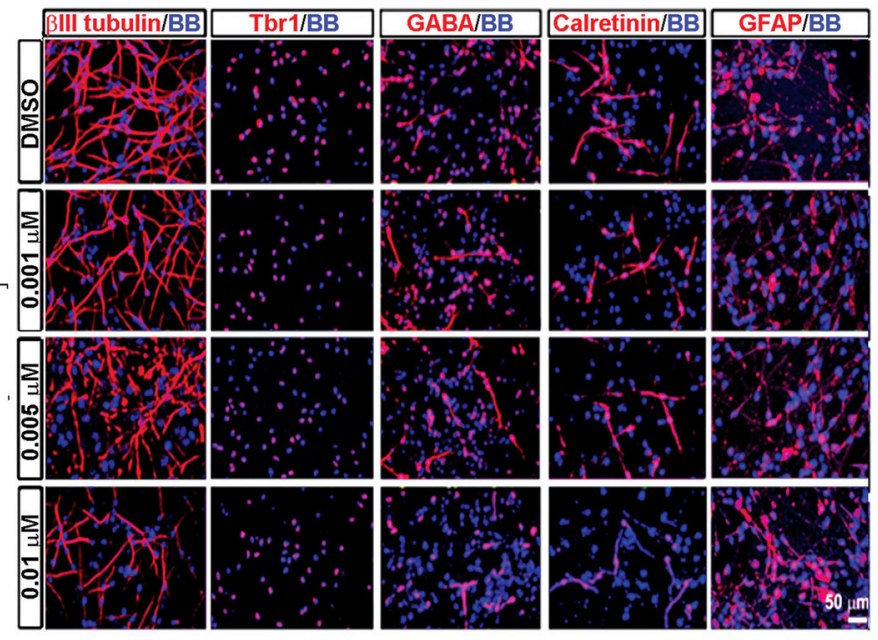

E

Quantification of Immunocytochemistry
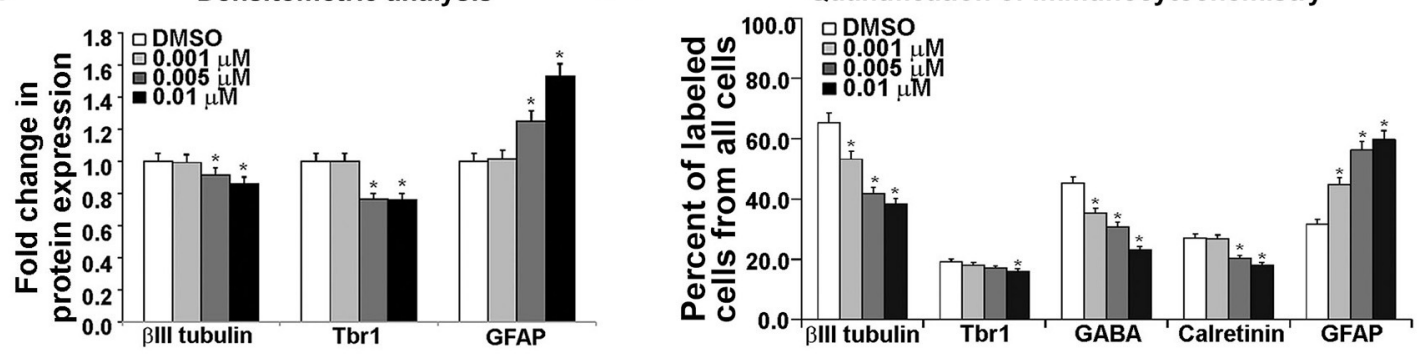

FIGURE 5 | Differential effect of KYNA treatment on neural cell types. (A) q-PCR showed that KYNA treatment decreased neuronal specific (Neurogenin, Tbr1, Gad65), but increased astrocytic gene (Gfap) expression (B) Western blot from $17 \mathrm{gw}$ KYNA treated cell lysates, and (C) Densitometric analysis showed a decrease in expression for neuron specific proteins, but an increase for astrocytic protein (D) Immunostaining at 17 gw for neuron and astrocytic markers (red); nuclei labeled with BB (blue). (E) Quantification of the immunolabeled cell types showed a decrease in neuronal cell populations, but an increase in the astrocyte cell population ( $n=4$; * represents $p<0.05)$.

KYNA treated mixed cell cultures with an antibody to $S 100 \beta$, a cytoplasmic marker for reactive astrocytes.

Quantification of the number of $\mathrm{S} 100 \beta^{+}$cells immediately after the $48 \mathrm{~h}$ KYNA treatment revealed that treatment with KYNA induced a significant increase in $S 100 \beta^{+}$cells, from $0.5 \%$ in control conditions to $40 \%$ when treated with $0.01 \mu \mathrm{M}$ KYNA $\left(p<0.001\right.$; Figure 6D). These $S 100 \beta^{+}$astrocytes were large cells with multiple processes. Reactive astrocytes are a well-known source of pro-inflammatory cytokines, one of which is IL-6, a primary cytokine released in almost all inflammatory responses (Guillemin et al., 2001; Islam et al., 2009). Since we observed a strong gliosis reaction in our KYNA-treated mixed cell cultures, we determined the level of secreted cytokine IL-6. We measured concentration of secreted IL-6 in the medium at 24 and $48 \mathrm{~h}$ after KYNA treatment, and observed significant increase in levels of IL- 6 in KYNA treated cultures, at both time points. These changes were concentration-dependent, as shown in Figure 6E. After $24 \mathrm{~h}$, the concentration of IL- 6 was increased in cells treated with all three concentrations of KYNA, however, significance was achieved only for concentrations $0.005 \mu \mathrm{M}$, and $0.01 \mu \mathrm{M}$ KYNA $(p<0.05)$, as compared to DMSO (control). After $48 \mathrm{~h}$, the IL-6 concentration was increased in all treated cell cultures regardless of KYNA concentration $(p<0.01)$. The possible reason why we did not observe differences in IL-6 levels between different concentrations of KYNA could be due to the saturation of essay sensitivity in presence of high concentrations of IL6.

\section{DISCUSSION}

In the present study, we explored the effects of KYNA on human cerebral cortical development in cell cultures derived from mid-gestational human tissue. Previous studies in rodents (Malatesta et al., 2000; Miyata et al., 2001; Noctor et al., 2001, 2004), and humans (Clowry et al., 2010; Hansen et al., 2010; Betizeau et al., 2013; Malik et al., 2013; Radonjić et al., 2014) have shown significant species-specific differences demonstrating critical need for studies of cortical development in human cultures. Three major findings from this study demonstrate that KYNA, acting as an antagonist of NMDARs, significantly alters proliferation, specification and differentiation of cortical cells generated from enriched RGC cultures. First, after KYNA treatment, RGC proliferation and survival decreased resulting 
A
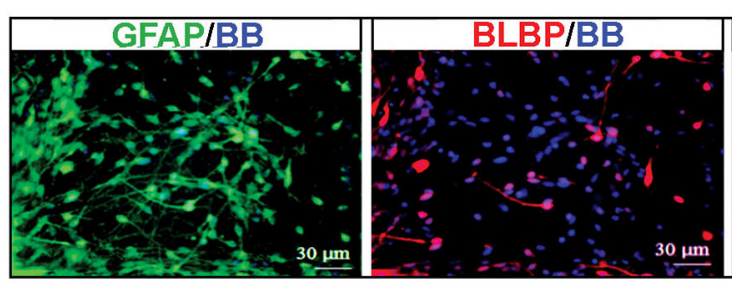

B
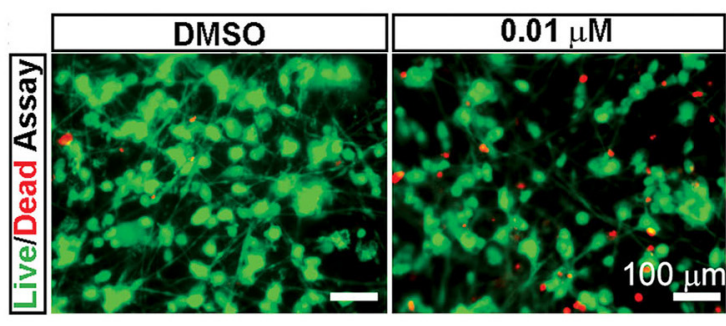

C
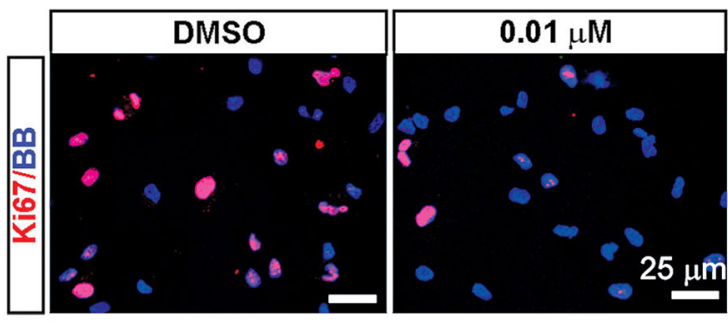

D
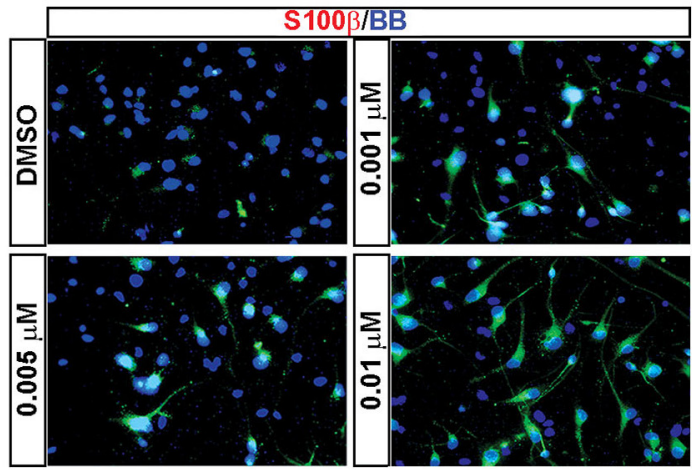

E

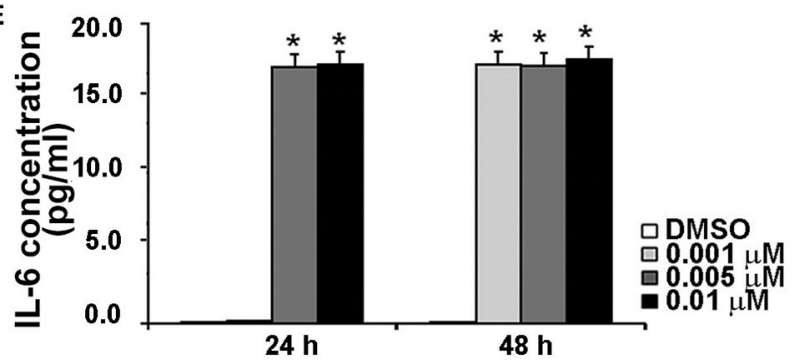

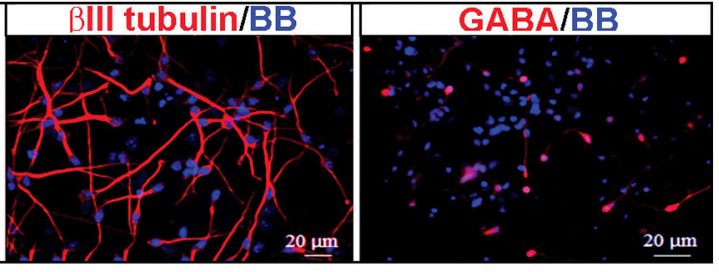
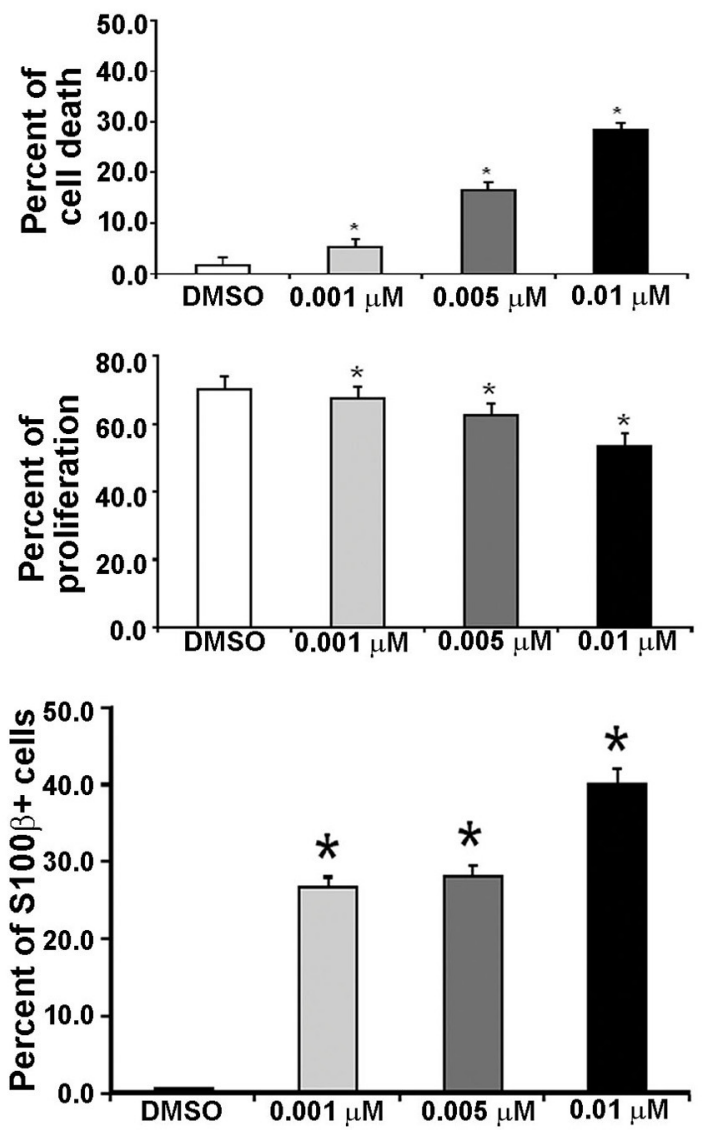

FIGURE 6 | KYNA treatment activated astrocytes and induced IL-6 secretion in mixed cell cultures. (A) Mixed cell cultures (18 gw) labeled with RGCs, astrocytes and neuronal markers. (B) The live/dead and (C) proliferation assays showed that KYNA treatment decreased cell viability and proliferation in a concentration-dependent manner. (D) Immunolabeling for S100b ${ }^{+}$(red). The percentage of S100 ${ }^{+}$reactive astrocytes increased after $48 \mathrm{~h}$ KYNA treatment. (E) KYNA treated cultures at 24 and $48 \mathrm{~h}$ time points exhibited increase in IL-6 secretion as compared to DMSO control. Nuclear stain: BB; $n=4$; ${ }^{*}$ represents $p<0.05$. Mean \pm SEM.

in a reduced number of cortical progenitors $\left(\mathrm{Nkx} 2.1^{+}\right.$and $\mathrm{Tbr}^{+}$cells), neurons ( $\beta$ III tubulin ${ }^{+}, \mathrm{Tbr}^{+}, \mathrm{CalR}^{+}$), and interneurons $\left(\mathrm{GABA}^{+}\right)$. Second, KYNA treatment effectively pushed the specification of RGCs toward the astroglial lineage, as evidenced by the increase in number of $\mathrm{GFAP}^{+}$cells after 3 DIV of proliferation. Not only did the number of $\mathrm{GFAP}^{+}$ 
astrocytes increase, but in addition astrocytes were activated as demonstrated by morphological changes and $S 100 \beta$ labeling. Third, KYNA exposure triggered an inflammatory response as evidenced by increased levels of the pro-inflammatory cytokine IL-6. In sum, these results indicate that altered levels of KYNA during human gestation, may have profound effects on cortical development, and through activation of astrocytes, initiate an inflammatory response resulting in a positive feedback loop.

\section{KYNA Disrupts Neurogenesis and Reduces the Pool of Cortical Progenitors In vitro}

KYNA is a product of the kynurenine pathway, the main metabolic route of tryptophan degradation, and is responsible for a broad spectrum of effects, including the endogenous regulation of neuronal excitability and the initiation of immune tolerance. KYNA is the only known endogenous antagonist of the NMDAR in vivo, and binds strongly to the NR1 subunit (Kessler et al., 1989; Wang et al., 2006). However, KYNA also inhibits $\alpha 7 n$ AChRs (Hilmas et al., 2001; Alkondon et al., 2004), and both NMDAR and nAChRs are expressed early during human development (4-5 gw; Kostović et al., 1989; HellströmLindahl et al., 1998; Suzuki et al., 2006). Therefore, it was necessary to distinguish which receptor mediates KYNA effects on the early developing brain. In this study, we showed that in RGCs, KYNA acts similar to NMDAR-specific antagonist D-APV, corroborating previous studies that showed KYNA's inability to block nAChR-dependent electrical activity in cultured adult rat cortical and hippocampal cells (Hilmas et al., 2001; Mok et al., 2009; Dobelis et al., 2012).

During embryonic development in rodents and humans, NMDARs are important for proliferation of neural stem cells, their differentiation into neurons and glia, and proper migration of the differentiated cell types to their correct position in the six-layered cerebral cortex (Manent et al., 2005; Suzuki et al., 2006; Toriumi et al., 2012). In vivo blockade of NMDARs during rat cortical development induces apoptosis of neuronal and glial cells leading to severe neurodegeneration and ultimately death of the animal (Ikonomidou et al., 1999). In vitro, we observed that antagonizing NMDARs with KYNA increases cell death of cortical progenitors and decreases RGC proliferation, showing the importance of NMDARs for both survival and proliferation of RGCs in the human cerebral cortex during the second trimester of gestation.

\section{KYNA-Induced Changes in Cell Fate Determination}

An important issue is whether KYNA has differential effects on generation of principal neurons and interneurons in the developing cortex. To study this question, we used various transcription factors to label distinct neuronal populations in vitro. Transcription factor Nkx2.1 is a marker of a subpopulation of cortical interneuron progenitors (Rakic and Zecevic, 2003; Zecevic et al., 2005; Jakovcevski et al., 2011), and Tbr2 is a marker of glutamatergic progenitors in the developing human cerebral cortex (Bayatti et al., 2008; Yu and Zecevic, 2011; Malik et al., 2013; Pollen et al., 2015). This study confirmed our previous results that human RGCs have a capacity to generate both $\mathrm{Nkx}_{2} .1^{+}$and Tbr2 ${ }^{+}$cells in vitro (Yu and Zecevic, 2011) and indicated further commitment of RGCs to both interneuron and glutamatergic lineages. For example, after allowing time for differentiation, a percentage of fetal cortical RGCs start expressing GABA a major interneuron transmitter. On similar grounds, after differentiation cortical RGCs were shown to express Tbr1, a transcription factor downstream of Tbr2, indicating commitment to the glutamatergic lineage (Englund et al., 2005). Most notably, we have shown that a KYNA-induced decrease in progenitors (Nkx2.1 and Tbr2) resulted further in a decrease of GABAergic interneurons and $\mathrm{Tbr}^{+}$glutamatergic neurons. Notably, the decrease of GABAergic neurons was more pronounced than that of glutamatergic neurons. These data suggest that a KYNA-induced alteration in the cortical progenitor pool disrupts neurogenesis and may affect the proportional balance of cortical cell types and subsequent formation of cortical circuitry.

\section{KYNA Elicits Pro-Inflammatory Response}

Mounting evidence suggests a link between maternal immune activation and neuropsychiatric illness (Gilmore and Jarskog, 1997; Buka et al., 2001). The KYNA-mediated NMDAR blockade favored astrocyte generation, as had been shown previously in human fetal astrocyte cultures (Guillemin et al., 2001), and in addition, induced the activation of resting astrocytes in both RGC cultures and mixed cell cultures. The morphology of S100 $\beta+$ cells changed, and their number increased, implying a pro-inflammatory response. Interestingly, astrocytic hypertrophy has been reported in the prefrontal cortex of patients with bipolar disorder (Rajkowska et al., 2001), indicating that reactive astrocytic changes can be a major component of neuropsychiatric illness.

We also showed increased levels of secreted IL-6, a proinflammatory cytokine, in our human culture medium following KYNA treatment. This is in agreement with reports in mice that KYNA causes the release of inflammatory cytokines, especially IL-6 and IFN- $\gamma$ (Islam et al., 2009). Moreover, in vitro, both IFN$\gamma$ and IL-6 activate human fetal astrocytes to synthesize large amounts of KYNA (Guillemin et al., 2001; Islam et al., 2009; Meyer et al., 2011; Schwieler et al., 2015). Activation of cytokines is directly relevant to schizophrenia as studies in human subjects found elevated levels of IL-6 in the cerebrospinal fluid of Sch patients in comparison to their age and sex-matched healthy counterparts (Garver et al., 2003; Schwieler et al., 2015). With respect to the potential developmental pathways involved, KYNA has been shown to elicit a pro-inflammatory response that can activate the JAK-STAT pathway in mice (Schwarcz et al., 2001; Erhardt et al., 2012; Holtze et al., 2012). This would result in cytokine-receptor interactions and could interfere with the normal specification of cortical progenitors at mid-gestation.

\section{Consequences of Elevated KYNA Levels during Fetal Neurodevelopment}

Metabolites of the kynurenine pathway have important roles in the CNS, and recent data imply a role in brain development as well (reviewed in Notarangelo and Pocivavsek, 2016). 
Physiological levels of KYNA are higher in the developing brain compared to the immediate post-natal period and adulthood (Beal et al., 1992; Walker et al., 1999; Ceresoli-Borroni and Schwarcz, 2000). It has been suggested that KYNA might protect the fetal brain from over-excitation via NMDARs (Badawy, 2014). At the same time, glutamate via activation of NMDARs has an important trophic role in neurodevelopment. Various insults during pregnancy can lead to direct physiological changes in the fetal environment, thereby influencing the normal course of prenatal brain development. For example, the anesthetic ketamine and drugs of abuse such as PCP and ethanol antagonize normal function of fetal cortical NMDARs (Anis et al., 1983; Krystal et al., 1994; Lahti et al., 1995; Lieberman et al., 2012; Xiang et al., 2015). These disruptions may have long-lasting consequences for subsequent brain and behavioral development and might lead to structural and functional brain abnormalities in adult life (Iaccarino et al., 2013).

Even though it is well established that KYNA acts as an antagonist of NMDAR and $\mathrm{nAChR}$, the consequences of pathological levels of KYNA in the developing brain have not been fully explored. Our in vitro study shows that KYNA, by antagonizing NMDARs, negatively influences the proliferation of human RGCs and pushes RGC specification toward astrocytes, vs. neurons. In addition, higher KYNA concentrations, while negatively impacting both interneurons and principle neurons, results in larger deficits in $\mathrm{GABA}^{+}$interneurons compared to a $\mathrm{Tbr}^{+}$subpopulation of projection neurons. The preferential vulnerability of interneurons might be clinically relevant since impaired function of cortical interneurons is reported in neurodevelopmental disorders including Sch and autism spectrum disorder (Akbarian et al., 1995; DeFelipe, 1999; Knable, 1999; Gleeson and Walsh, 2000; Lewis and Levitt, 2002; Levitt, 2003; Baraban and Tallent, 2004; Lewis et al., 2005). In our study, human cortical progenitors were isolated at mid-gestation (16-19 gw), an important period of active neurogenesis when upper cortical layers are formed (Hill and Walsh, 2005). As these layers are crucial for formation of cortico-cortical connections and subsequently for emergence of higher brain functions, interference with NMDARs that are expressed on all cortical cell types (Bagasrawala et al., 2016) at this developmentally sensitive period may lead to a widespread effect on formation of the

\section{REFERENCES}

Akbarian, S., Huntsman, M. M., Kim, J. J., Tafazzoli, A., Potkin, S. G., Bunney, W. E. Jr., et al. (1995). GABAA receptor subunit gene expression in human prefrontal cortex: comparison of schizophrenics and controls. Cereb. Cortex 5, 550-560. doi: 10.1093/cercor/5.6.550

Akbarian, S., Sucher, N. J., Bradley, D., Tafazzoli, A., Trinh, D., Hetrick, W. P., et al. (1996). Selective alterations in gene expression for NMDA receptor subunits in prefrontal cortex of schizophrenics. J. Neurosci. 6, 19-30.

Alkondon, M., Pereira, E. F., Yu, P., Arruda, E. Z., Almeida, L. E., Guidetti, P., et al. (2004). Targeted deletion of the kynurenine aminotransferase ii gene reveals a critical role of endogenous kynurenic acid in the regulation of synaptic transmission via alpha7 nicotinic receptors in the hippocampus. J. Neurosci. 24, 4635-4648. doi: 10.1523/JNEUROSCI.5631-03.2004 cortical circuitry. Together, these changes can have a negative impact on cortical functional maturation during adolescence, a stage when cognitive executive functions, such as planning, rational thinking, attention, and emotion-related impulsivity control develop, and a time point at which Sch symptoms often first manifest (Uhlhaas, 2011). The effects of KYNA on human cortical progenitors in vitro, reported in this study, are still preliminary. Further studies are, therefore, needed to determine if KYNA exerts its effect on RGCs by a selective or inductive action mechanism.

Certainly, in vitro systems have limitations, and further studies are needed to discern the complexity of developmental disruption caused by NMDAR antagonism. However, the in vitro system studied here serves as an innovative tool for understanding the possible effects of endogenous molecules, when present at pathologic levels, on human fetal cortical development. This method enables us to identify the specific cellular targets of KYNA but also to determine possible cell signaling molecules involved in human cortical development.

\section{AUTHOR CONTRIBUTIONS}

IB did all experiments, analyzed data and was involved in writing the results. NZ substantially contributed in all aspect of this study. NR substantially contributed in design of the study, analysis and writing the results.

\section{FUNDING}

This work was supported by NIH grants 2R01NSO41489 and subcontract 5R01DA023999-07(NZ).

\section{ACKNOWLEDGMENTS}

Human fetal tissue was procured from Albert Einstein College of Medicine, Tissue Repository, Bronx, NY, USA, and the Joint MRC/Welcome Trust (grant no. 099175/Z/12/Z Human Developmental Biology Resource (http://hdbr.org), Newcastle upon Tyne, England. We thank Dr. Lynn Selemon for her valuable scientific and editorial input.
Anis, N. A., Berry, S. C., Burton, N. R., and Lodge, D. (1983). The dissociative anaesthetics, ketamine and phencyclidine, selectively reduce excitation of central mammalian neurones by $\mathrm{N}$-methyl-aspartate. Br. J. Pharmacol. 79, 565-575. doi: 10.1111/j.1476-5381.1983.tb11031.x

Badawy, A. A. B. (2014). The tryptophan utilization concept in pregnancy. Obstet. Gynecol. Sci. 57, 249-259. doi: 10.5468/ogs.2014.57.4.249

Bagasrawala, I., Memi, F., Radonjić, N. V., and Zecevic, N. (2016). N-methyl daspartate receptor expression patterns in the human fetal cerebral cortex. Cereb. Cortex. doi: 10.1093/cercor/bhw289. [Epub ahead of print].

Balasz, R. (2006). Trophic effect of glutamate. Curr. Top. Med. Chem. 6, 961-968. doi: 10.2174/156802606777323700

Bale, T. L., Baram, T. Z., Brown, A. S., Goldstein, J. M., Insel, T. R., McCarthy, M. M., et al. (2010). Early life programming and neurodevelopmental disorders. Biol. Psychiatry 68, 314-319. doi: 10.1016/j.biopsych.2010.05.028 
Baraban, S. C., and Tallent, M. (2004). Interneuron Diversity series: interneuronal neuropeptides-endogenous regulators of neuronal excitability. Trends Neurosci. 27, 135-142. doi: 10.1016/j.tins.2004.01.008

Bayatti, N., Sarma, S., Shaw, C., Eyre, J. A., Vouyiouklis, D. A., Lindsay, S., et al. (2008). Progressive loss of PAX6, TBR2, NEUROD and TBR1 mRNA gradients correlates with translocation of EMX2 to the cortical plate during human cortical development. Eur. J. Neurosci. 28, 1449-1456. doi: 10.1111/j.14609568.2008.06475.x

Beal, M. F., Swartz, K. J., and Isacson, O. (1992). Developmental changes in brain kynurenic acid concentrations. Brain Res. Dev. Brain Res. 68, 136-139. doi: 10.1016/0165-3806(92)90256-V

Belforte, J. E., Zsiros, V., Sklar, E. R., Jiang, Z., Yu, G., Li, Y., et al. (2010). Postnatal NMDA receptor ablation in corticolimbic interneurons confers schizophrenialike phenotypes. Nat. Neurosci. 13, 76-83. doi: 10.1038/nn.2447

Betizeau, M., Cortay, V., Patti, D., Pfister, S., Gautier, E., Bellemin-Menard, A., et al. (2013). Precursor diversity and complexity of lineage relationships in the outer subventricular zone of the primate. Neuron 80, 442-457. doi: 10.1016/j.neuron.2013.09.032

Breier, A., Malhotra, A. K., Pinals, D. A., Weisenfeld, N. I., and Pickar, D. (1997). Association of ketamine-induced psychosis with focal activation of the prefrontal cortex in healthy volunteers. Am. J. Psychiatry 154, 805-811. doi: 10.1176/ajp.154.6.805

Brown, A. S. (2012). Epidemiologic studies of exposure to prenatal infection and risk of schizophrenia and autism. Dev. Neurobiol. 72, 1272-1276. doi: 10.1002/dneu.22024

Brown, A. S., and Derkits, E. J. (2010). Prenatal infection and schizophrenia: a review of epidemiologic and translational studies. Am. J. Psychiatry 167, 261-280. doi: 10.1176/appi.ajp.2009.09030361

Buka, S. L., Tsuang, M. T., Torrey, E. F., Klebanoff, M. A., Bernstein, D., and Yolken, R. H. (2001). Maternal infections and subsequent psychosis among offspring. Arch. Gen. Psychiatry 58, 1032-1037. doi: 10.1001/archpsyc.58.11.1032

Ceresoli-Borroni, G., and Schwarcz, R. (2000). Perinatal kynurenine pathway metabolism in the normal and asphyctic rat brain. Amino Acids 19, 311-323. doi: $10.1007 / \mathrm{s} 007260070062$

Clowry, G., Molnar, Z., and Rakic, P. (2010). Renewed focus on the developing human neocortex. J. Anat. 217, 276-288. doi: 10.1111/j.1469-7580.2010.01281.x

Coyle, J. T. (1996). The glutamatergic dysfunction hypothesis for schizophrenia. Harv. Rev. Psychiatry. 3, 241-253. doi: 10.3109/10673229609017192

DeFelipe, J. (1999). Chandelier cells and epilepsy. Brain 122, 1807-1822. doi: 10.1093/brain/122.10.1807

Deutsch, S. I., Mastropaolo, J., Schwartz, B. L., Rosse, R. B., and Morihisa, J. M. (1989). A 'glutamatergic hypothesis' of schizophrenia. Rationale for pharmacotherapy with glycine. Clin. Neuropharmacol. 12, 1-13. doi: 10.1097/00002826-198902000-00001

Dobelis, P., Staley, K. J., and Cooper, D. C. (2012). Lack of modulation of Nicotinic Acetylcholine alpha-7 receptor currents by Kynurenic acid in adult hippocampal interneurons. PLOS ONE 7:e41108. doi: 10.1371/journal.pone.0041108

Englund, C., Fink, A., Lau, C., Pham, D., Daza, R. A. M., Bilfone, A., et al. (2005). Pax6, Tbr2, and Tbr1 are expressed sequentially by radial glia, intermediate progenitor cells, and postmitotic neurons in developing neocortex. J. Neurosci. 25, 247-251. doi: 10.1523/JNEUROSCI.2899-04.2005

Erhardt, S., Blennow, K., Nordin, C., Skogh, E., Lindstrom, L. H., and Engberg, G. (2001). Kynurenic acid levels are elevated in the cerebrospinal fluid of patients with schizophrenia. Neurosci. Lett. 313, 96-98. doi: 10.1016/S03043940(01)02242-X

Erhardt, S., Lim, C. K., Linderholm, K. R., Janelidze, S., Lindqvist, D., Samuelsson, M., et al. (2012). Connecting inflammation with glutamate agonism in suicidality. Neuropsychopharmacology 38, 743-752. doi: 10.1038/npp.2012.248

Garver, D. L., Tamas, R. L., and Holcomb, J. A. (2003). Elevated interleukin-6 in the cerebrospinal fluid of a previously delineated schizophrenia subtype. Neuropsychopharmacology 28, 1515-1520. doi: 10.1038/sj.npp.1300217

Gilmore, J. H., and Jarskog, L. F. (1997). Exposure to infection and brain development: cytokines in the pathogenesis of schizophrenia. Schizophr. Res. 24, 365-167. doi: 10.1016/S0920-9964(96)00123-5
Gleeson, J. G., and Walsh, C. A. (2000). Neuronal migration disorders: from genetic diseases to developmental mechanisms. Trends Neurosci. 23, 352-359. doi: 10.1016/S0166-2236(00)01607-6

Guillemin, G. J., Kerr, S. J., Smythe, G. A., Smith, D. G., Kapoor, V., Armati, P. J., et al. (2001). Kynurenine pathway metabolism in human astrocytes: a paradox for neuronal protection. J. Neurochem. 78, 842-853. doi: 10.1046/j.14714159.2001.00498.x

Hansen, D. V., Lui, J. H., Flandin, P., Yosjikawa, K., Rubenstein, J. L., AlvarezBuylla, A., et al. (2013). Non-epithelial stem cells and cortical interneuron production in the human ganglionic eminences. Nat. Neurosci. 16, 1576-1587. doi: $10.1038 / \mathrm{nn} .3541$

Hansen, D. V., Lui, J. H., Parker, P. R., and Kriegstein, A. R. (2010). Neurogenic radial glia in the outer subventricular zone of human neocortex. Nature 464, 554-561. doi: $10.1038 /$ nature 08845

Haydar, T. F., Wang, F., Schwartz, M. L., and Rakic, P. (2000). Differential modulation of proliferation in the neocortical ventricular and subventricular zones. J. Neurosci. 20, 5764-5774.

Hellström-Lindahl, E., Gorbounova, O., Seiger, A., Mousavi, M., and Nordberg, A. (1998). Regional distribution of nicotinic receptors during prenatal development of human brain and spinal cord. Brain Res. Dev. Brain Res. 108, 147-160. doi: 10.1016/S0165-3806(98)00046-7

Heyes, M. P., Mefford, I. N., Quearry, B. J., Dedhia, M., and Lackner, A. (1990). Increased ratio of quinolinic acid to kynurenic acid in cerebrospinal fluid of D retrovirus-infected rhesus macaques: relationship to clinical and viral status. Ann. Neurol. 27, 666-675. doi: 10.1002/ana.410270614

Hill, R. S., and Walsh, C. A. (2005). Molecular insights into human brain evolution. Nature 437, 64-67. doi: 10.1038/nature04103

Hilmas, C., Pereira, E. F., Alkondon, M., Rassoulpour, A., Schwarcz, R., and Albuquerque, E. X. (2001). The brain metabolite kynurenic acid inhibits alpha7 nicotinic receptor activity and increases non-alpha7 nicotinic receptor expression: physiopathological implications. J. Neurosci. 21, 7463-7474.

Holtze, M., Saetre, P., Engberg, G., Schweiler, L., Werge, T., Andreassen, O. A., et al. (2012). Kynurenine 3-monooxygenase polymorphisms: relevance for kynurenic acid synthesis in patients with schizophrenia and healthy controls. $J$. Psychiatry Neurosci. 37, 53-57. doi: 10.1503/jpn.100175

Howard, B., Chen, Y., and Zecevic, N. (2006). Cortical progenitor cells in the developing human telencephalon. Glia 53, 57-66. doi: 10.1002/glia.20259

Iaccarino, H. F., Suckow, R. F., Xie, S., and Bucci, D. J. (2013). The effect of transient increases in kynurenic acid and quinolinic acid levels early in life on behavior in adulthood: implications for schizophrenia. Schizophr. Res. 150, 392-397. doi: 10.1016/j.schres.2013.09.004

Ikonomidou, C., Bosch, F., Miksa, M., Bittigau, P., Vockler, J., Dikranian, K., et al. (1999). Blockade of NMDA receptors and apoptotic neurodegeneration in the developing brain. Science 283, 70-74. doi: 10.1126/science.283.5398.70

Islam, O., Gong, X., Rose-John, S., and Heese, K. (2009). Interleukin-6 and neural stem cells: more than gliogenesis. Mol. Biol. Cell. 20, 188-199. doi: 10.1091/mbc.E08-05-0463

Jakovcevski, I., Mayer, N., and Zecevic, N. (2011). Multiple origins of human neocortical interneurons are supported by distinct expression of transcription factors. Cereb. Cortex 21, 1771-1782. doi: 10.1093/cercor/bhq245

Kessler, M., Terramani, T., Lynch, G., and Baudry, M. (1989). A glycine site associated with $\mathrm{N}$-methyl-D-aspartic acid receptors: characterization and identification of a new class of antagonists. J. Neurochem. 52, 1319-1328. doi: 10.1111/j.1471-4159.1989.tb01881.x

Knable, M. B. (1999). Schizophrenia and bipolar disorder: findings from studies of the stanley foundation brain collection. Schizophr. Res. 39, 149-152. doi: 10.1016/S0920-9964(99)00114-0

Kostović, I., Lukinović, N., Judas, M., Bogdanović, N., Mrzljak, L., Zecević, N., et al. (1989). Structural basis of the developmental plasticity in the human cerebral cortex: the role of the transient subplate zone. Metab. Brain Dis. 4, 17-23. doi: 10.1007/BF00999489

Krystal, J. H., Karper, L. P., Seibyl, J. P., Freeman, G. K., Delaney, R., Bremner, J. D., et al. (1994). Subanesthetic effects of the noncompetitive NMDA antagonist, ketamine, in humans. Psychotomimetic, perceptual, cognitive, and neuroendocrine responses. Arch. Gen. Psychiatry 51, 199-214. doi: 10.1001/archpsyc.1994.03950030035004 
Lahti, A. C., Koffel, B., LaPorte, D., and Tamming, C. A. (1995). Subanesthetic doses of ketamine stimulate psychosis in schizophrenia. Neuropsychopharmacology 31, 9-19. doi: 10.1016/0893-133X(94)00131-I

Levitt, P. (2003). Structural and functional maturation of the developing primate brain. J. Pediatr. 143, 35-45. doi: 10.1067/S0022-3476(03)00400-1

Lewis, D. A., Hashimoto, T., and Volk, D. W. (2005). Cortical inhibitory neurons and schizophrenia. Nat. Rev. Neurosci. 6, 312-324. doi: 10.1038/nrn1648

Lewis, D. A., and Levitt, P. (2002). Schizophrenia as a disorder of neurodevelopment. Аnnu. Rev. Neurosci. 25, 409-432. doi: 10.1146/annurev.neuro.25.112701.142754

Lieberman, R., Levine, E. S., Kranzler, H. R., Abreu, C., and Covault, J. (2012). Pilot study of iPS-derived neural cells to examine biologic effects of alcohol on human neurons in vitro. Alcohol. Clin. Exp. Res. 36, 1678-1687. doi: 10.1111/j.1530-0277.2012.01792.x

Limosin, F., Rouillon, F., Payan, C., Cohen, J. M., and Strub, N. (2003). Prenatal exposure to influenza as a risk factor for adult schizophrenia. Acta Psychiatr. Scand. 107, 331-335. doi: 10.1034/j.1600-0447.2003.00052.x

LoTurco, J. J., Wanton, M. G., and Kriegstein, A. R. (1991). Initial expression and endogenous activation of NMDA channels in early neocortical development. J. Neurosci. 17, 792-799.

Lui, J. H., Hansen, D. V., and Kriegstein, A. R. (2011). Development and evolution of the human neocortex. Cell 146, 18-36. doi: 10.1016/j.cell.2011.06.030

Ma, T., Wang, C., Wang, L., Zhou, X., Tian, M., Zhang, Q., et al. (2013). Subcortical origins of human and monkey neocortical interneurons. Nat. Neurosci. 16, 1588-1597. doi: 10.1038/nn.3536

Malatesta, P., Hartfuss, E., and Götz, M. (2000). Isolation of radial glial cells by fluorescent-activated cell sorting reveals a neuronal lineage. Development 127 , 5253-5263.

Malik, S., Vinukonda, G., Vose, L. R., Diamond, D., Bhimvarapu, B. B. R., $\mathrm{Hu}, \mathrm{F}$, et al. (2013). Neurogenesis continues in the third trimester of pregnancy and is suppressed by premature birth. J. Neurosci. 33, 411-423. doi: 10.1523/JNEUROSCI.4445-12.2013

Manent, J. B., Demarque, M., Jorquera, I., Pellegrino, C., Ben-Ari, Y., Aniksztejn, L., et al. (2005). A noncanonical release of GABA and glutamate modulates neuronal migration. J. Neurosci. 25, 4755-4765. doi: 10.1523/JNEUROSCI.0553-05.2005

Meyer, U., Weiner, I., McAlonan, G. M., and Feldon, J. (2011). The neuropathological contribution of prenatal inflammation to schizophrenia. Expert Rev. Neurother. 11, 29-32. doi: 10.1586/ern.10.169

Miyata, T., Kawaguchi, A., Okano, H., and Ogawa, M. (2001). Asymmetric inheritance of radial glial fibers by cortical neurons. Neuron 31, 727-741. doi: 10.1016/S0896-6273(01)00420-2

Mo, Z., Moore, A. R., Filipovic, R., Ogawa, Y., Kazuhiro, I., Antic, S. D., et al. (2007). Human cortical neurons originate from radial glia and neuron-restricted progenitors. J. Neurosci. 27, 4132-4145. doi: 10.1523/JNEUROSCI.0111-07.2007

Mo, Z., and Zecevic, N. (2009). Human fetal radial glia cells generate oligodendrocytes in vitro. Glia 57, 490-498. doi: 10.1002/glia.20775

Mok, M. H., Fricker, A. C., Weil, A., and Kew, J. N. (2009). Electrophysiological characterisation of the actions of kynurenic acid at ligand-gated ion channels. Neuropharmacology 57, 242-249. doi: 10.1016/j.neuropharm.2009.06.003

Noctor, S. C., Flint, A. C., Weissman, T. A., Dammerman, R. S., and Kriegstein, A. R. (2001). Neurons derived from radial glial cells establish radial units in neocortex. Nature 409, 714-720. doi: 10.1038/35055553

Noctor, S. C., Martínez-Cerdeño, V., Ivic, L., and Kriegstein, A. R. (2004). Cortical neurons arise in symmetric and asymmetric division zones and migrate through specific phases. Nat. Neurosci. 7, 136-144. doi: 10.1038/nn1172

Notarangelo, F. M., and Pocivavsek, A. (2016). Elevated kynurenine pathway metabolism during neurodevelopment: implications for brain and behavior. Neuropharmacology 16, 30073-30079. doi: 10.1016/j.neuropharm.2016.03.001

Pilowsky, L. S., Bressan, R. A., Stone, J. M., Erlandsson, K., Mulligan, R. S., Krystal, J. H., et al. (2006). First in vivo evidence of an NMDA receptor deficit in medication-free schizophrenic patients. Mol. Psychiatry 11, 118-119. doi: 10.1038/sj.mp.4001751

Pocivavsek, A., Thomas, M. A. R., Elmer, G. I., Bruno, J. P., and Schwarcz, R. (2014). Continuous kynurenine administration during the prenatal period, but not during adolescence, causes learning and memory deficits in adult rats. Psychopharmacology (Berl). 231, 2799-2809. doi: 10.1007/s00213-014-3452-2
Pollen, A. A., Nowakowski, T. J., Chen, J., Retallack, H., Sandoval-Espinosa, C., Nicholas, C. R., et al. (2015). Molecular Identity of human outer radial glia during cortical development. Cell 163, 55-67. doi: 10.1016/j.cell.2015.09.004

Radonjić, N. V., Memi, F., Ortega, J. A., Glidden, N., Zhan, H., and Zecevic, N. (2014). The role of sonic hedgehog in the specification of human cortical progenitors in vitro. Cereb. Cortex 26, 131-143. doi: 10.1093/cercor/bhu183

Radonjić, N. V., Petroijevic, N. D., Vuckovic, S. M., Prostran, M. S., Nesic, Z. I., Todorovic, V. R., et al. (2008). Baseline temperature in an animal model of schizophrenia: long-term effects of perinatal phencyclidine administration. Physiol. Behav. 93, 437-443. doi: 10.1016/j.physbeh.2007.10.003

Rajkowska, G., Halaris, A., and Selemon, L. D. (2001). Reductions in neuronal and glial density characterize the dorsolateral prefrontal cortex in bipolar disorder. Biol. Psychiatry 49, 741-752. doi: 10.1016/S0006-3223(01)01080-0

Rakic, S., and Zecevic, N. (2003). Emerging complexity of layer I in human cerebral cortex. Cereb. Cortex 13, 1072-1083. doi: 10.1093/cercor/13.10.1072

Rujescu, D., Bender, A., Keck, M., Hartmann, A. M., Ohl, F., Raeder, H., et al. (2006). A pharmacological model for psychosis based on N-methyl-Daspartate receptor hypofunction: molecular, cellular, functional and behavioral abnormalities. Biol. Psychiatry 59, 721-729. doi: 10.1016/j.biopsych.2005.08.029

Sathyasaikumar, K. V., Stachowski, E. K., Wonodi, I., Roberts, R. C., Rassoulpour, A., McMahon, R. P., et al. (2011). Impaired kynurenine pathway metabolism in the prefrontal cortex of individuals with schizophrenia. Schizophr. Bull. 37, 1147-1156. doi: 10.1093/schbul/sbq112

Scharfman, H. E., and Goodman, J. H. (1998). Effects of central and peripheral administration of kynurenic acid on hippocampal evoked responses in vivo and in vitro. Neuroscience 86, 751-764. doi: 10.1016/S0306-4522(98)00073-6

Schwarcz, R., Rassoulpour, A., Wu, H. Q., Medoff, D., Tamminga, C. A., and Roberts, R. C. (2001). Increased cortical kynurenate content in schizophrenia. Biol. Psychiatry 50, 521-530. doi: 10.1016/S0006-3223(01)01078-2

Schwieler, L., Larsson, M. K., Skogh, E., Kegel, M. E., Orhan, F., Abdelmaoty, S., et al. (2015). Increased levels of IL-6 in the cerebrospinal fluid of patients with chronic schizophrenia-significance for activation of the kynurenine pathway. J. Psychiatry Neurosci. 40, 126-133.

Selemon, L. D., and Zecevic, N. (2015). Schizophrenia: a tale of two critical periods for prefrontal cortical development. Transl. Psychiatry. 5, 1-11. doi: 10.1038/tp.2015.115

Stöber, G., Franzek, E., Beckmann, H., and Schmidtke, A. (2002). Exposure to prenatal infections, genetics and the risk of systematic and periodic catatonia. J. Neural Transm. 109, 921-929. doi: 10.1007/s007020200075

Stone, T. W. (2013). Neuropharmacology of quinolinic and kynurenic acids. Pharmacol. Rev. 45, 309-379.

Suzuki, M., Nelson, A. D., Eickstaedt, J. B., Wallace, K., Wright, L. S., and Svendsen, C. N. (2006). Glutamate enhances proliferation and neurogenesis in human neural progenitor cell cultures derived from the fetal cortex. Eur. J. Neurosci. 24, 645-653. doi: 10.1111/j.1460-9568.2006.04957.x

Toriumi, K., Mouri, A., Narusawa, S., Aoyama, Y., Ikawa, N., Lu, L., et al. (2012). Prenatal NMDA receptor antagonism impaired proliferation of neuronal progenitor, leading to fewer glutamatergic neurons in the prefrontal cortex. Neuropharmacology 37, 1387-1396. doi: 10.1038/npp.2011.324

Uhlhaas, P. J. (2011). The adolescent brain: implications for the understanding, pathophysiology, and treatment of schizophrenia. Schizophr. Bull. 37, 480-483. doi: $10.1093 /$ schbul/sbr025

Walker, D. W., Curtis, B., Lacey, B., and Nitsos, I. (1999). Kynurenic acid in brain and cerebrospinal fluid of fetal, newborn, and adult sheep and effects of placental embolization. Pediatr. Res. 45, 820-826. doi: 10.1203/00006450199906000-00007

Wang, C., McInnis, J., Ross-Sanchez, M., Shinnick-Gallagher, P., Wiley, J. L., and Johnson, K. M. (2001). Long-term behavioral and neurodegenerative effects of perinatal phencyclidine administration: implications for schizophrenia. Neuroscience 107, 535-550. doi: 10.1016/S0306-4522(01) 00384-0

Wang, J., Simonavicius, N., Wu, X., Swaminath, G., Raegan, J., Tian, H., et al. (2006). Kynurenic acid as a ligand for orphan G protein-coupled receptor GPR35. J. Biol. Chem. 281, 22021-22028. doi: 10.1074/jbc.M6035 03200

Wright, P., Takei, N., Rifkin, L., and Murray, R. M. (1995). Maternal influenza, obstetric complications, and schizophrenia. Am. J. Psychiatry 152, 1714-1720. doi: 10.1176/ajp.152.12.1714 
Xiang, Y., Kim, K. Y., Gelernter, J., Park, I. H., and Zhang, H. (2015). Ethanol upregulates NMDA receptor subunit gene expression in human embryonic stem cell-derived cortical neurons. PLOS ONE 10:e0134907. doi: 10.1371/journal.pone.0134907

Yu, X., and Zecevic, N. (2011). Dorsal radial glial cells have the potential to generate cortical interneurons in human but not in mouse brain. J. Neurosci. 31, 2413-2420. doi: 10.1523/JNEUROSCI.524910.2011

Zecevic, N., Chen, Y., and Filipovic, R. (2005). Contributions of cortical subventricular zone to the development of the human cerebral cortex. J. Comp. Neurol. 491, 109-122. doi: 10.1002/cne.20714

Zhuravlev, A. V., Shchegolev, B. F., Savvateeva-Popova, E. V., and Popov, A. V. (2007). Stacking-interactions in the control-gear binding of kynurenic acid with
NR2A- and GluR2-subunits of glutamate ionotropic receptors. Ross Fiziol $\mathrm{Zh}$ Im I M Sechenova 93, 609-624.

Conflict of Interest Statement: The authors declare that the research was conducted in the absence of any commercial or financial relationships that could be construed as a potential conflict of interest.

Copyright (C) 2016 Bagasrawala, Zecevic and Radonjić. This is an open-access article distributed under the terms of the Creative Commons Attribution License (CC BY). The use, distribution or reproduction in other forums is permitted, provided the original author(s) or licensor are credited and that the original publication in this journal is cited, in accordance with accepted academic practice. No use, distribution or reproduction is permitted which does not comply with these terms. 